\title{
Hereditary Connective Tissue Diseases in Young Adult Stroke: A Comprehensive Synthesis
}

\author{
Olivier M. Vanakker, ${ }^{1}$ Dimitri Hemelsoet, ${ }^{2}$ and Anne De Paepe ${ }^{1}$ \\ ${ }^{1}$ Center for Medical Genetics, Ghent University Hospital, De Pintelaan 185, 9000 Ghent, Belgium \\ ${ }^{2}$ Department of Neurology, Ghent University Hospital, De Pintelaan 185, 9000 Ghent, Belgium
}

Correspondence should be addressed to Olivier M. Vanakker, olivier.vanakker@ugent.be

Received 15 September 2010; Revised 15 December 2010; Accepted 23 December 2010

Academic Editor: Turgut Tatlisumak

Copyright (c) 2011 Olivier M. Vanakker et al. This is an open access article distributed under the Creative Commons Attribution License, which permits unrestricted use, distribution, and reproduction in any medium, provided the original work is properly cited.

\begin{abstract}
Though the genetic background of ischaemic and haemorrhagic stroke is often polygenetic or multifactorial, it can in some cases result from a monogenic disease, particularly in young adults. Besides arteriopathies and metabolic disorders, several connective tissue diseases can present with stroke. While some of these diseases have been recognized for decades as causes of stroke, such as the vascular Ehlers-Danlos syndrome, others only recently came to attention as being involved in stroke pathogenesis, such as those related to Type IV collagen. This paper discusses each of these connective tissue disorders and their relation with stroke briefly, emphasizing the main clinical features which can lead to their diagnosis.
\end{abstract}

\section{Introduction}

Epidemiological studies on stroke, one of the prominent causes of death and disability in the Western world, have revealed a strong genetic influence in its pathogenesis, with conventional risk factors contributing only up to $40 \%-$ $50 \%$ of stroke risk [1]. Often stroke represents a complex polygenetic or multifactorial disease, hampering the identification of causal genes. However, in some individualsparticularly young adults—stroke can result from a monogenic disorder [2, 3]. Next to arteriopathies (Cerebral Autosomal Dominant of Autosomal Recessive Arteriopathy with Stroke-like Episodes and LeucoencefalopathyCADASIL and CARASIL, resp.) or metabolic diseases (Fabry, homocystinuria), several connective tissue disorders (CTD) can involve ischaemic or haemorrhagic stroke as part of the phenotype in young adults. Moreover, several extracellular matrix (ECM) components have been (suggested to be) implicated in stroke pathogenesis [4].

The connective tissue is a basic type of tissue providing structural and metabolic support for other tissues and organs throughout the body. Its uniqueness, compared to other tissues, lies in its composition of a diverse set of constituentscells, fibres, blood vessels-scattered around in an ECM.
Four types of macromolecules can be distinguished in the ECM: collagen, elastin, glycoproteins and proteoglycans.

Heritable disorders that involve connective tissue are among the most common genetic diseases in humans. Their classification is not without challenge because of the phenotypic variability within and between families which characterizes several of these disorders. Classification also tends to overemphasize the aetiologic differences between severe genetic disorders that are apparent in infants or young children and the more common diseases that appear later in life. Yet these late-onset diseases, such as aneurysms and stroke, can be caused or influenced by single-gene variants. Because of the wide distribution of connective tissues within the human body, diseases that affect connective tissue cells or ECM proteins often have systemic effects. Based on the two major constituents of the connective tissue, collagen and elastin, these disorders can be divided into "collagenopathies" and "elastinopathies" [5, 6].

Awareness for and recognition of such connective tissue disorders has a broad relevance as their identification has implications not only for counselling, recurrence risk and risk for associated manifestations, but also for management and prognosis. This paper attempts to present a comprehensive review of the most important connective tissue 
diseases to consider when confronted with stroke in young adults. Also some promising candidate genes encoding ECM proteins will be discussed briefly.

\section{Disorders Affecting the Collagens}

Collagens are triple helical proteins formed when three polypeptide chains, called alpha chains, wind around each other to form a collagen molecule. The collagen superfamily of proteins is a major component of the ECM and contains the most abundant proteins in the body which are classified into 29 collagen types [7]. A wide spectrum of diseases has been associated with the collagens, caused by mutations in at least 27 different collagen-associated genes [5]. Of them, the Ehlers-Danlos syndromes, osteogenesis imperfecta, autosomal dominant polycystic kidney disease and collagen Type IV can be related to stroke.

2.1. The Ehlers Danlos Syndrome. The Ehlers-Danlos syndrome (EDS) is a clinically and genetically heterogeneous group of connective tissue disorders, affecting approximately 1 in 5000 individuals $[8,9]$. It can be catagorized into several types, based on the phenotypical and molecular characteristics (Table 1).

The classic and hypermobility type are characterised by various expression of joint hypermobility and related complications, easy bruising and atrophic scarring. In contrast, the vascular type of EDS (Type IV) presents with a distinct tissue fragility of the vasculature, colon and uterus, while hypermobility and bruising are less prominent [810]. Particularly in the latter, autosomal dominant form, haemorrhagic or ischaemic stroke may occur at young age [11].

EDS Type IV (OMIM no. 130050) results from mutations in the COL3A1 gene, encoding Type III procollagen (chrom. $2 \mathrm{q} 31$ ); the mutation spectrum is broad with novel mutations being a common finding (approximately 50\%). The mutant Type III collagen has reduced strength, elasticity and healing properties as well as defective integration into the normal ECM, resulting in the typical EDS IV phenotype [10]. This encompasses a typical facial appearance (thin nose and lips, sunken cheeks, small chin), thin skin and fragile arteries and intestines which tend to rupture (Figure 1) [10]. Neurovascular complications are seen in approximately $10 \%$ of patients and include intracerebral aneurysms of large and medium-sized arteries and (spontaneous) dissection of carotid and vertebral arteries, often without prior dilatation [12-17]. Aneurysms typically develop in the cavernous sinus or just as the carotid artery emerges from the sinus and bilateral carotid aneurysms have been reported [18]. These may be associated with other complications such as spontaneous carotid-cavernous fistulas [18-20]. Also, arterial tortuosity, ectasia and dilatation or stenosis have been described in EDS Type IV [21].

The diagnosis of EDS Type IV is based on clinical examination, biochemical analysis of the collagens on cultured skin fibroblasts and molecular analysis of the COL $3 \mathrm{~A} 1$ gene $[10,16]$. No current aetiological treatment is available and management focuses on counselling and symptomatic control. In this respect, management dilemmas may arise when confronted with a vascular EDS patient, as the extreme tissue fragility makes interventional or surgical procedures to medicate, for example, aneurysms less obvious, as they are associated with a tremendous risk for morbidity (especially haemorrhages) and mortality $[18,22,23]$.

2.2. Type IV Collagen-Related Small Vessel Disease. Type IV collagen comprises a family of triple helical isoforms consisting of at least six genetically distinct chains with tissue-specific distribution. The heterotrimer isoform consisting of one alpha-1 and two alpha-2 chains, encoded by the COL4A1 gene (chrom. 13q34) and COL4A2 gene (chrom. 13q34), respectively, is located a.o. in the basement membrane of arteries throughout the body [24]. Mutations in COL4A1 have already been established in autosomal dominant porencephaly and infantile hemiparesis $[25,26]$. A Col4a1 knock-out mouse model predisposes newborn and adult mice to intracerebral haemorrhage, with predominance in the basal ganglia. In addition, these knock-out mice showed retinal tortuosity together with glomerular basement membrane defects [27].

Recently, COL4A1 gene mutations have been recognized as the cause of small vessel disease in adults presenting with either ischaemic stroke or intracerebral haemorrhage [2830]. The mean age of onset was 36 years (range: 14-49yrs.). In a majority of the young adults, small vessel disease was the presenting symptom. Other associated features may include previous history of infantile hemiparesis, seizures, cognitive impairment and a familial history of migraine [27, 31]. As in mice, these patients often have retinal arteriolar tortuosity in fundo [27, 31]. Also renal and muscular involvement has been documented. The association of a hereditary angiopathy, nephropathy, aneurysm and muscle cramps has been defined as the HANAC syndrome [32, 33]. These patients were shown to have microvascular brain disease and single or multiple intracranial aneurysms (primarily on the carotid siphon), together with retinal arteriolar tortuosity, cystic renal disease with thickened renal basement membrane featuring hematuria and muscle cramps with elevated creatinine kinase, possibly due to transient ischaemia or microhaemorrhages [32, 33].

The diagnosis of collagen Type IV -associated stroke can be made on brain imaging, featuring frequent leukoaraiosis, subcortical microbleeds, lacunar infarction and dilated perivascular spaces in conjunction with systemic features or positive familial history [27]. Additional investigations should include a funduscopic examination and renal evaluation. A skin biopsy has been suggested a useful examination in HANAC syndrome, with significant ultrastructural anomalies including replication of the lamina densa, altered dermal arteriolar wall morphology and dissociation of vascular smooth muscle cells [33]. No data are available on ultrastructural changes of the skin in nonHANAC COL4A1 patients. Molecular confirmation can be obtained by COL4A1 sequencing. So far, only missense mutations have been reported involving highly conserved glycine residues in 
TABLE 1: Villefranche classification of Ehlers-Danlos syndrome (1998).

\begin{tabular}{|c|c|c|c|}
\hline Type & Inheritance & Gene(s) & Phenotype \\
\hline Classic EDS (Types I/II) & $\mathrm{AD}$ & $\begin{array}{l}\text { COL5A1, } \\
\text { COL5A2 }\end{array}$ & Hyperelastic, soft skin, atrophic scars, easy bruising, joint hyperlaxity \\
\hline Hypermobility EDS (Type III) & $\mathrm{AD}$ & Unknown & Gross joint hyperlaxity, mild atrophic scarring and easy bruising \\
\hline Vascular EDS (Type IV) & $\mathrm{AD}$ & COL3A1 & $\begin{array}{l}\text { Typical facial gestalt, skin fragility, extreme vascular fragility, rupture } \\
\text { of uterus and colon }\end{array}$ \\
\hline Kyphoscoliosis EDS (Type VI) & AR & PLOD & $\begin{array}{l}\text { Marfanoid habitus, hypotonia, kyphoscoliosis, ocular complications } \\
+ \text { features of Type I EDS }\end{array}$ \\
\hline $\begin{array}{l}\text { Arthrochalasis EDS } \\
\text { (Types VIIA and B) }\end{array}$ & $\mathrm{AD}$ & $\begin{array}{l}\text { COl1A1, } \\
\text { COL1A2 }\end{array}$ & $\begin{array}{l}\text { Severe joint hyperlaxity, congenital bilateral hip dyslocation, easy } \\
\text { bruising, scoliosis, hypotonia }\end{array}$ \\
\hline $\begin{array}{l}\text { Dermatosparaxis EDS } \\
\text { (Type VII C) }\end{array}$ & AR & $\begin{array}{l}\text { Procollagen, } \\
\text { N-peptidase }\end{array}$ & Severe skin fragility, sagging redundant skin, excessive bruising \\
\hline
\end{tabular}

AD: autosomal dominant; AR: autosomal recessive.

a triple helical domain of the gene. It is currently unclear whether a solid genotype-phenotype correlation is present, though it has been suggested that the mutation site may relate to the phenotype, as the HANAC-associated mutations are closely related [28].

Management of individuals with a COL4A1 mutation is symptomatic. As cerebral haemorrhage often occurred following trauma or anticoagulant therapy, both in mice and humans, the prevention of trauma and avoidance of risk factors for bleeding may decrease the risk for (repetitive) haemorrhaging in these patients [27].

2.3. Osteogenesis Imperfecta. Osteogenesis imperfecta (OI) is a heterogeneous group of heritable connective tissue disorders characterised by fragile and brittle bones, blue sclerae, dental malformations, deafness and hyperextensible ligaments (Figure 2) [34, 35]. Different subtypes can be recognized with a broad range in severity, from mild to lethal (Sillence classification, Table 2) [36]. The inheritance modus of OI includes both autosomal dominant and recessive forms, caused by mutations in different genes (COL1A1, COL1A2, LEPRE1, CRTAP, FKBP10, PPIB) [34, 35, 37-39]. Most patients have a mutation in one of the genes encoding Type I collagen, COL1A1 (chrom. 17q21.31-q22) and COL1A2 (chrom. 7q22.1). Type I collagen, a heterotrimer similar to Type IV collagen, has a broad tissue distribution, including bone and vessel wall $[34,35]$.

COL1A1 and COL1A2 mutations will induce a diminished or aberrant production of osseous and vascular Type I collagen which in return will lead to diminished resistance of bone against repetitive stress as well as to the reported aortic dissection or ulnar artery aneurysms [37, 40, 41]. In the fully developed brain, Type I collagen can be found predominantly in and around large arteries [42]. Details on neurovascular involvement in OI are however scarce. The complications which have been reported, although infrequent, include ruptured cerebral aneurysm associated with fenestrated vertebral arteries, moyamoya-like disease, carotid-cavernous fistula, cervical and vertebral artery dissection [43-45].

The diagnosis of OI is based on familial history and a history of fractures, clinical and radiological examination, biochemical analysis of the collagens and molecular sequencing of the OI-associated genes [34, 35].

The objective of treatment in OI is maximal mobility and functionality via physiotherapy and revalidation. Intravenous bisphosphonates have also been generally accepted as part of the treatment with positive effect on bone density and cortical thickness $[34,35,46]$.

2.4. Autosomal Dominant Polycystic Kidney Disease. Autosomal dominant polycystic kidney disease (ADPKD, OMIM\# $613095,173900)$ is an adult onset multisystem disorder characterised by bilateral renal cysts, cystic changes in other organs such as liver or pancreas, and vascular abnormalities, including dilatation and dissection of the aorta and intracranial aneurysms [47]. Its prevalence at birth is between $1: 400$ and $1: 1000$. There is evidence that ADPKD is a collagen matrix disease, as histological evaluation of resected kidney specimens showed dilated and tortuous parenchymous blood vessels as well as excessive and oedematous collagenous tissue. The weak and excessive collagen is suggested to play a central role in the pathogenesis of different manifestations of ADPKD [48]. ADPKD is caused by mutations in the PKD1 (chrom. 16p13.3-p13.12) or PKD2 gene (chrom. 4q21-q23), encoding polycystin 1 and 2, respectively, [47]. Though clinical manifestations of both types overlap, PKD1 is associated with more severe disease than $P K D 2$, with larger kidneys and earlier onset of renal failure [49]. Polycystin 1 is thought to be a membrane protein, involved in cell-to-cell or cell-matrix interactions, whereas polycystin 2 is thought to be a channel protein. The mechanisms contributing to cystogenesis are complex and are beyond the purpose of this paper [50].

The most frequent neurovascular complication of ADPKD is intracranial aneurysms, occurring in approximately $10 \%$ of patients, with a higher prevalence $(22 \%)$ in those individuals with a positive familial history of intracranial haemorrhage $[51,52]$. Most of these aneurysms are asymptomatic. However, the mean age of rupture is considerably lower, being 39 years in ADPKD patients versus 51 years in the general population. At the time of rupture, most patients still have normal renal function, though hypertension is often noted [53]. 


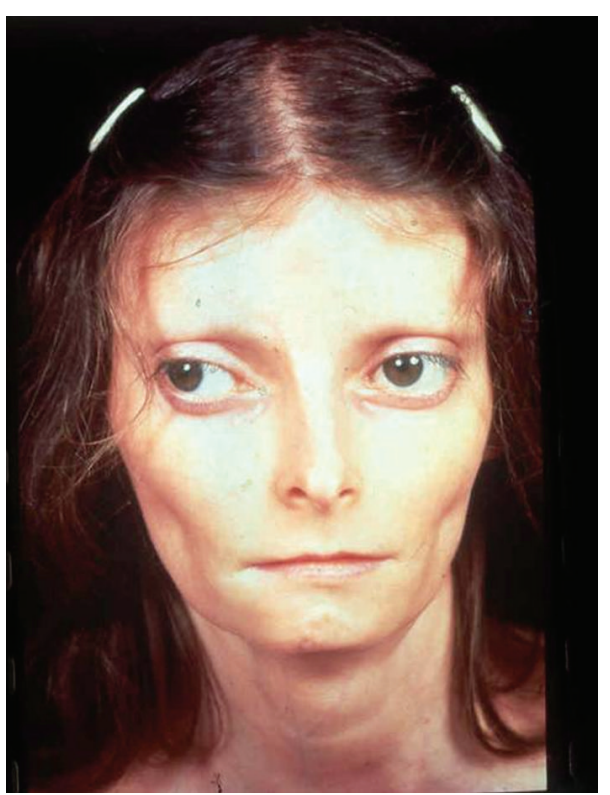

(a)

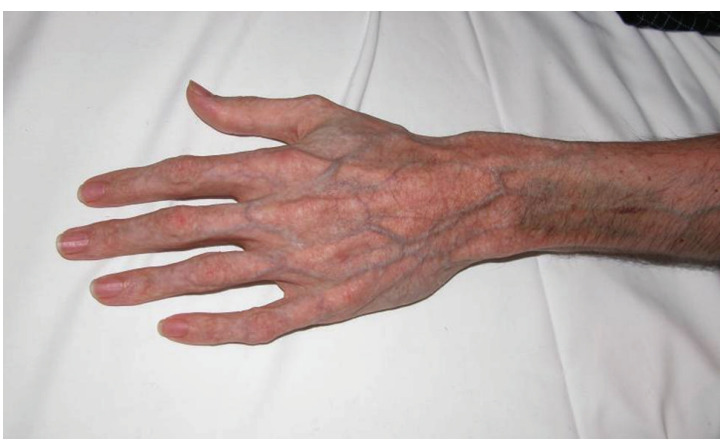

(c)

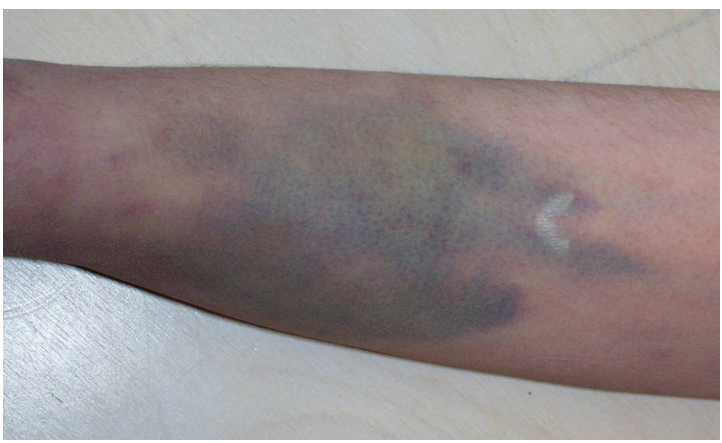

(d)

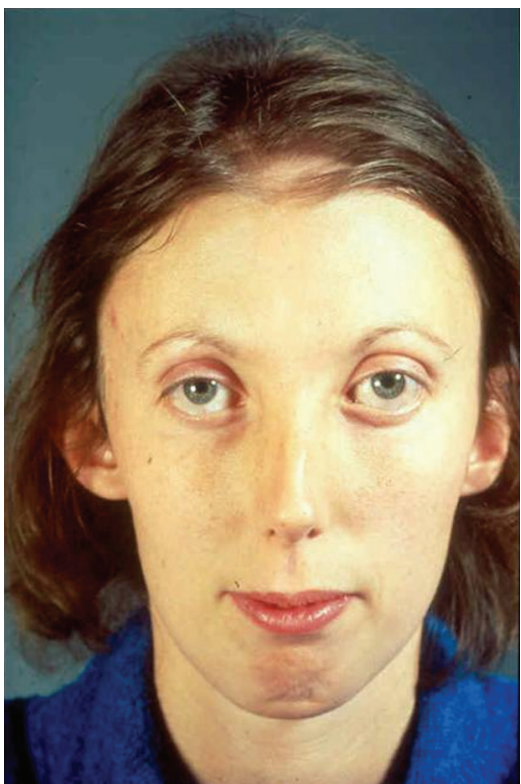

(b)
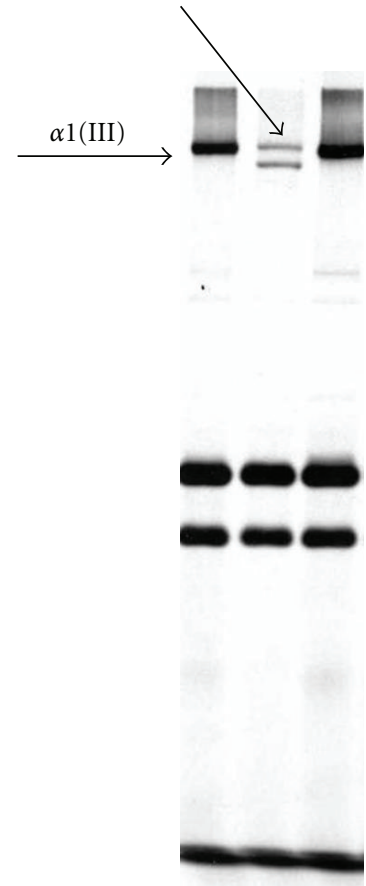

(e)

FIgURE 1: Clinical and biochemical characteristics of the vascular Ehlers-Danlos syndrome. Typical facial features with diminished subcutaneous fat, thin nose and lips (a, b), acrogeria (c) and easy bruising (d). Biochemical analysis of the collagens reveals a diminished amoun of collagen Type III (e).

For the diagnosis of ADPKD, renal ultrasonography is commonly used with highly predictive ultrasound diagnostic criteria being available. Molecular confirmation can be done using DNA linkage or gene-based direct sequencing. Screening should be performed in affected patients for extrarenal manifestations of the disease. Particularly in those patients with a positive family history of intracranial aneurysms, an MRI angiography should be included [54].

Management is directed toward reducing morbidity and mortality from the renal and extrarenal complications of 


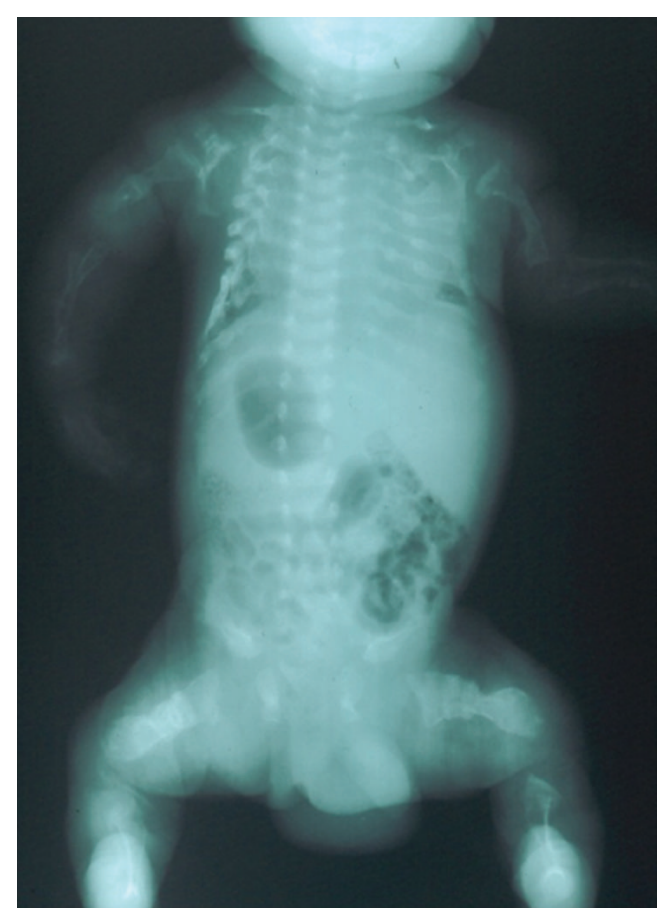

(a)

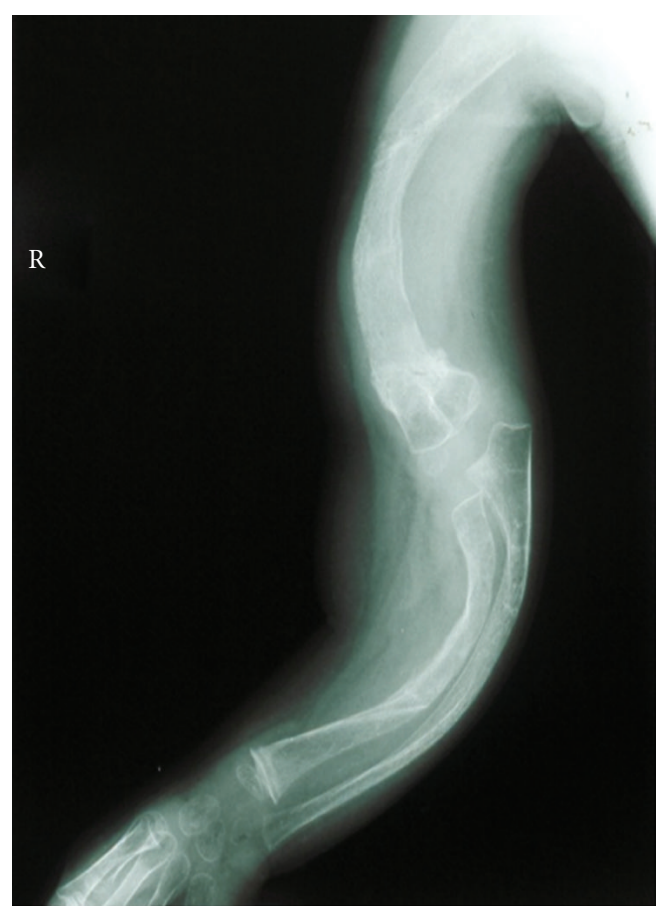

(b)

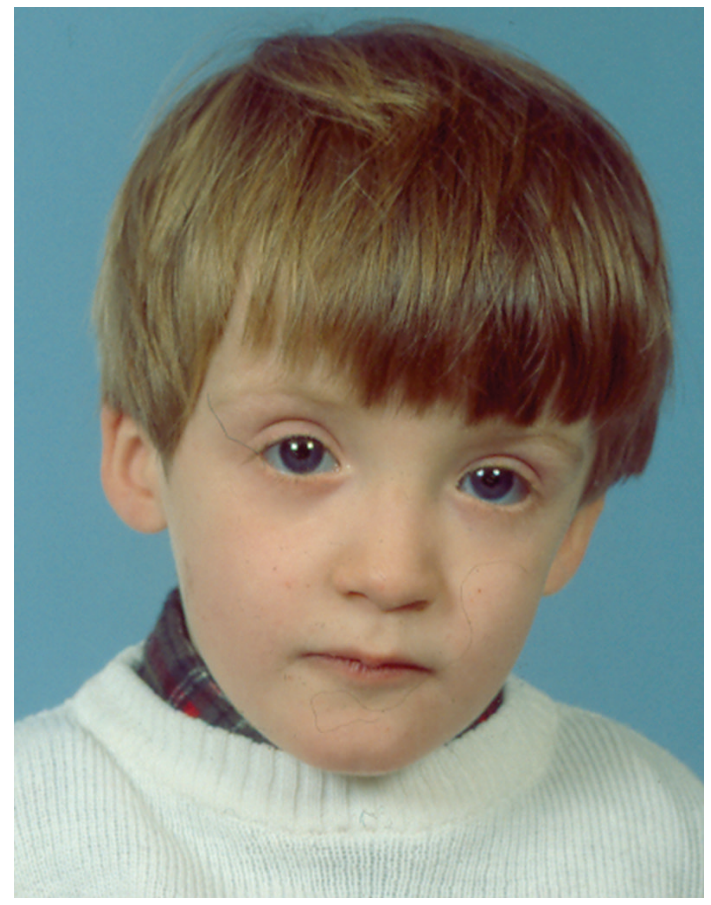

(c)

FIgURE 2: Clinical features of osteogenesis imperfecta. Osteopenia and multiple fractures (a), bone deformities (b) and blue sclerae (c).

the disease and includes antihypertensive medication, cyst decompression, control of hyperlipidemia and dietary protein restriction $[51,55,56]$. Symptomatic cerebral aneurysms are usually treated by surgical clipping. Asymptomatic aneurysms are closely followed at yearly interval; controversy exists whether surgery is required at a diameter of more than $5 \mathrm{~mm}$ or $10 \mathrm{~mm}$ [57]. The main-stay therapy for ruptured or symptomatic intracranial aneurysm is surgical clipping. In some cases, endovascular treatment (coiling) may be indicated [51]. 
TABLE 2: Silence classification of osteogenesis imperfecta.

\begin{tabular}{|c|c|c|c|}
\hline Type & Inheritance & Gene(s) & Phenotype \\
\hline OI Type I & $\mathrm{AD}$ & COL1A1 & $\begin{array}{l}\text { Fractures, osteopenia, blue sclerae, severe hearing loss, dentinogenesis } \\
\text { imperfecta in some }\end{array}$ \\
\hline OI Type II & $\mathrm{AD}$ & $\begin{array}{l}\text { COl1A } 1 \\
\text { COL1A2 }\end{array}$ & $\begin{array}{l}\text { Multiple fractures, severe osteopenia and bone deformation, short } \\
\text { stature, blue sclerae }\end{array}$ \\
\hline OI Type III & $\mathrm{AD} / \mathrm{AR}$ & $\begin{array}{l}\text { COl1A } 1 \\
\text { COL1A2 }\end{array}$ & $\begin{array}{l}\text { Triangular face, severe scoliosis, fractures, osteopenia and bone } \\
\text { deformities, short stature, bleu sclerae, hearing loss, dentinogenesis } \\
\text { imperfecta in some }\end{array}$ \\
\hline OI Type IV & $\mathrm{AD}$ & $\begin{array}{l}\text { COl1A } 1 \\
\text { COL1A2 }\end{array}$ & $\begin{array}{l}\text { Fractures, osteopenia and bone deformities, hearing impairment, } \\
\text { dentinogenesis imperfecta, short stature in some }\end{array}$ \\
\hline OI Type V & $\mathrm{AD}$ & Unknown & $\begin{array}{l}\text { Fractures, osteopenia and bone deformities, hearing impairment, } \\
\text { dentinogenesis imperfecta, short stature in some, often luxation of } \\
\text { head of radial bone }\end{array}$ \\
\hline OI Type VI & $?$ & FKBP10 & $\begin{array}{l}\text { Multiple fractures, osteopenia and bone deformities, hearing } \\
\text { impairment, short stature in some, accumulation of osteoid in bone }\end{array}$ \\
\hline OI Type VII & $\mathrm{AR}$ & CRTAP & $\begin{array}{l}\text { Multiple fractures, osteopenia and bone deformation, blue sclerae, } \\
\text { rhizomelia, coxa vara }\end{array}$ \\
\hline OI Type VIII & $\mathrm{AR}$ & LEPRE1 & $\begin{array}{l}\text { Multiple fractures, severe osteopenia and bone deformation, short } \\
\text { stature, blue sclerae in some }\end{array}$ \\
\hline
\end{tabular}

AD: autosomal dominant; AR: autosomal recessive. Characteristics which may be of value in discriminating the subtypes are marked in italics.

\section{Disorders Affecting Elastic Fibres}

The elastic fibre system forms a network responsible for the resilience and elasticity of various tissues. It consists of interconnecting fibres of varying diameter, containing two distinct components: elastin, a well-characterised connective tissue protein and elastin-associated microfibrils, the components of which include fibrillin, a microfibrilassociated glycoprotein. The biology of elastic fibres is complex because of its multiple associated molecules, tightly regulated developmental pattern of deposition, multi-step assembly, unique elastomeric properties and influence on cell phenotype. Several hallmark connective tissue disorders, such as Marfan syndrome or pseudoxanthoma elasticum, are caused by abnormalities of the elastic fibres, and can be related to stroke.

\subsection{Pseudoxanthoma Elasticum and the PXE-Like Syndrome.} Pseudoxanthoma elasticum (PXE, OMIM\# 264800) is an autosomal recessive disorder characterised by skin, ocular and cardiovascular symptoms resulting from ectopic mineralization and fragmentation of elastic fibres [58, 59]. It is caused by mutations in the ABCC6 gene (chrom. 16p13.1), encoding an ATP-binding transporter protein, the substrate and (patho)physiological role of which remain currently unknown [60]. Recent insights have revealed deficient vitamin $\mathrm{K}$-dependent calcification inhibitors-due to low serum vitamin $\mathrm{K}$ in PXE patients-to induce the ectopic mineralization of elastic fibres [61]. The skin phenotype exists of yellowish papules of degraded elastic fibres in the flexural areas of the body, coalescing into larger plaques, sometimes associated with the presence of additional skin folds (Figure 3) [58, 59]. The PXE retinopathy, based on elastic fibre abnormalities in the Bruch's membrane, involves angioid streaks and subretinal neovascularisation, resulting in retinal haemorrhages and vision loss (Figure 3) [58, 59]. Cardiovascular complications exist of coronary and peripheral artery disease (hypertension, myocardial infarction, claudication), gastrointestinal haemorrhage as well as predominantly ischaemic stroke. The latter was found in $15 \%$ of PXE patients, with a mean age of onset of 49 years $[58,59]$. Intracerebral haemorrhage has been described in rare cases of PXE [62].

Heterozygous carriers of 1 ABCC6 mutation do not tend to develop symptomatic skin or ocular manifestations of PXE, but do have an increased cardiovascular risk [59, 6365]. In addition, it has been shown that a significantly higher proportion of heterozygous ABCC6 carriers can be found in an ischaemic stroke population compared to normal controls, suggesting it to be a molecular risk factor for ischaemic stroke (Vanakker et al., unpublished data).

In 2007, we described a novel autosomal recessive PXElike syndrome (OMIM\# 610842), characterised by a severe cutaneous phenotype with thick and redundant skin folds beyond the flexural areas, a mild retinopathy and a deficiency of the vitamin K-dependent coagulation factors (Figure 4) [66]. This disease was shown to be caused by mutations in the GGCX gene, encoding a gamma-carboxylase which performs an essential posttranslational modification step of several vitamin K-dependent proteins, such as clotting factors and mineralization inhibitors. In two of the originally described patients, cerebral aneurysms were present, one of which had recurrent cerebral aneurysms [66]. It is however at present unclear whether these are actually part of the phenotype or a coincidental finding.

The diagnosis of PXE should be thought of in the presence of skin or ocular symptoms and can be confirmed by skin biopsy and molecular sequencing of the ABCC6 gene [59]. Depending on the phenotype, including cutis laxa and a clotting deficiency, GGCX sequencing may be appropriate 


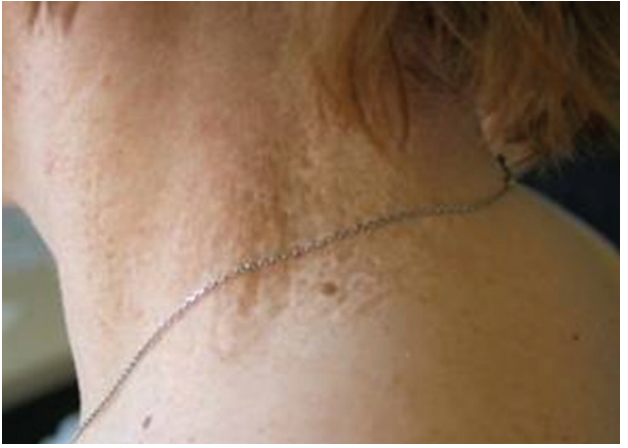

(a)

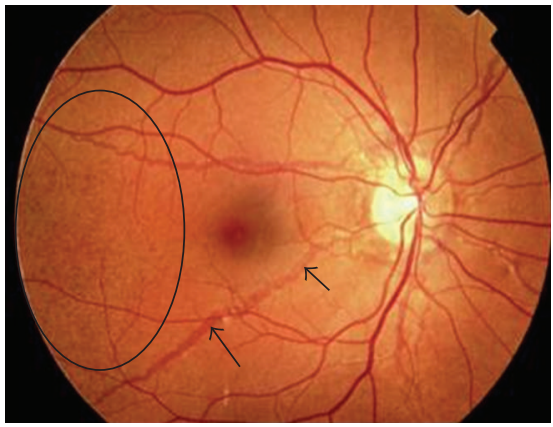

(d)

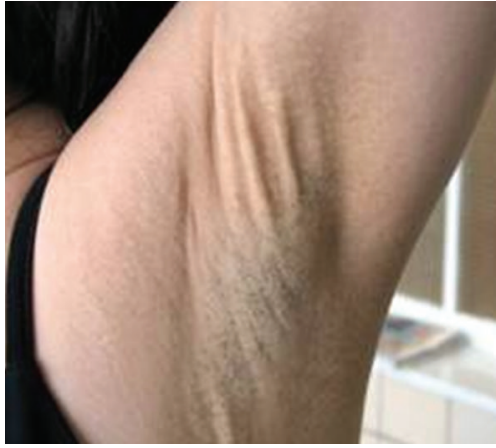

(b)

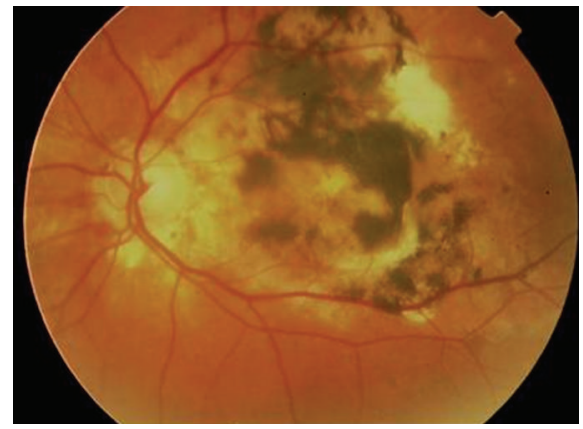

(e)

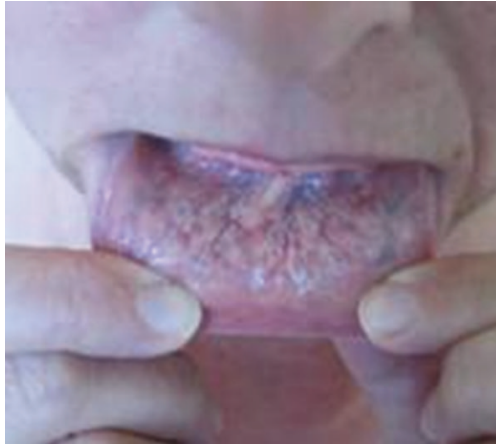

(c)

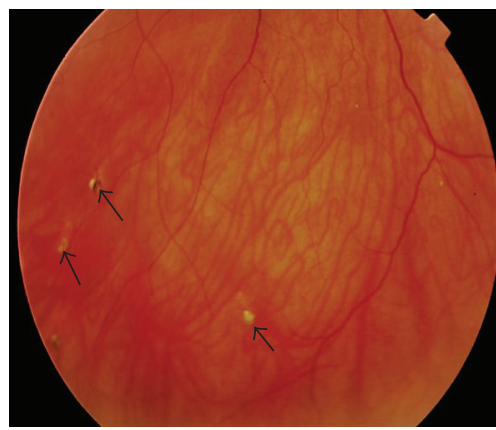

(f)

Figure 3: Cutaneous and ophthalmological symptoms of PXE. Plaques of papules in the neck region (a), increased skin laxity (b) and mucosal involvement with yeloowish pattern on the inner lip (c). The retinopathy consists of peau d'orange (d, oval), angioid streaks (d, arrowed), retinal hemorrhaging (e). In some cases calcifications of Bruch's membrane can be seen as comets or comet tails (f, arrowed).

[66]. In view of the number of heterozygotes in a general ischaemic stroke population, $A B C C 6$ analysis is suggested as a diagnostic option in young individuals suffering ischaemic stroke, with no significant conventional risk factors.

In the absence of an aetiological therapy, management of PXE is focussed on the prevention and treatment of complications [59]. Anti-VEGF antibodies, such as bevacuzimab or ranibizumab, are used to treat ocular complications such as neovascularisation, with significant success [67]. Other aspects of management include cardiovascular prevention measures and avoidance of anticoagulants, nonsteroidal antiinflammatory drugs and head trauma [59]. Particularly the relative contra-indication for anticoagulant therapy in PXE patients, because of the ocular and gastrointestinal bleeding diathesis, can create a therapeutic dilemma for which no ideal solution exists. An individual assessment should be made in each patient of the benefits and risks of starting such therapy, taking into account the specifics of the patients' phenotype.

3.2. Marfan Syndrome. The Marfan syndrome (MFS, OMIM\# 154700) is an autosomal dominant multisystemic disorder characterised by skeletal (marfanoid habitus with tall stature, arachnodactyly, pectus deformity and joint hypermobility), ophthalmological (ectopia lentis, myopia) and cardiovascular symptoms (aortic root dilatation) (Figure 5) [68]. It is caused by mutations in the FBN1 gene (chrom. 15q21.1), encoding the ECM protein fibrillin 1, expressed in the heart and elastic arteries [69]. In about 25\% of probands, this mutation occurs de novo [69].

The most frequent neurovascular complication in MFS is an extension of an aortic dissection into the common carotid artery [70]. Spontaneous dissections limited to the common or internal carotid artery have also been reported [71]. In a large retrospective study, Wityk et al. described a neurovascular event in approximately 3.5 percent of Marfan patients, most of which were TIAs $(65 \%)$, cerebral infarctions (most often cardioembolic, 10\%), spinal cord infarctions $(10 \%)$, subdural haematomas $(10 \%)$ or spinal subarachnoid haemorrhage (5\%) [72]. A conclusive relationship between MFS and intracranial aneurysms has not been established $[73,74]$.

The clinical diagnosis of Marfan syndrome can be made based on the revised Ghent nosology criteria and confirmed molecularly by analysis of the FBN1 gene [75]. Treatment of the MFS involves the use of beta-blockade and angiotensinconverting enzyme inhibition therapy to achieve reduction of hemodynamic stress and delay the progression of arterial dilatation. When critical dilatation of the aorta occurs, with significant risk for aortic dissection or rupture, aortic root replacement surgery is performed $[76,77]$.

3.3. Loeys-Dietz Syndrome. Loeys-Dietz syndrome (LDS, OMIM\# 608967, 609192, 610168, 610380) is an autosomal dominant disease caused by mutations in the transforming growth factor beta receptor 1 or 2 (TGFBR1 and TGFBR2, 

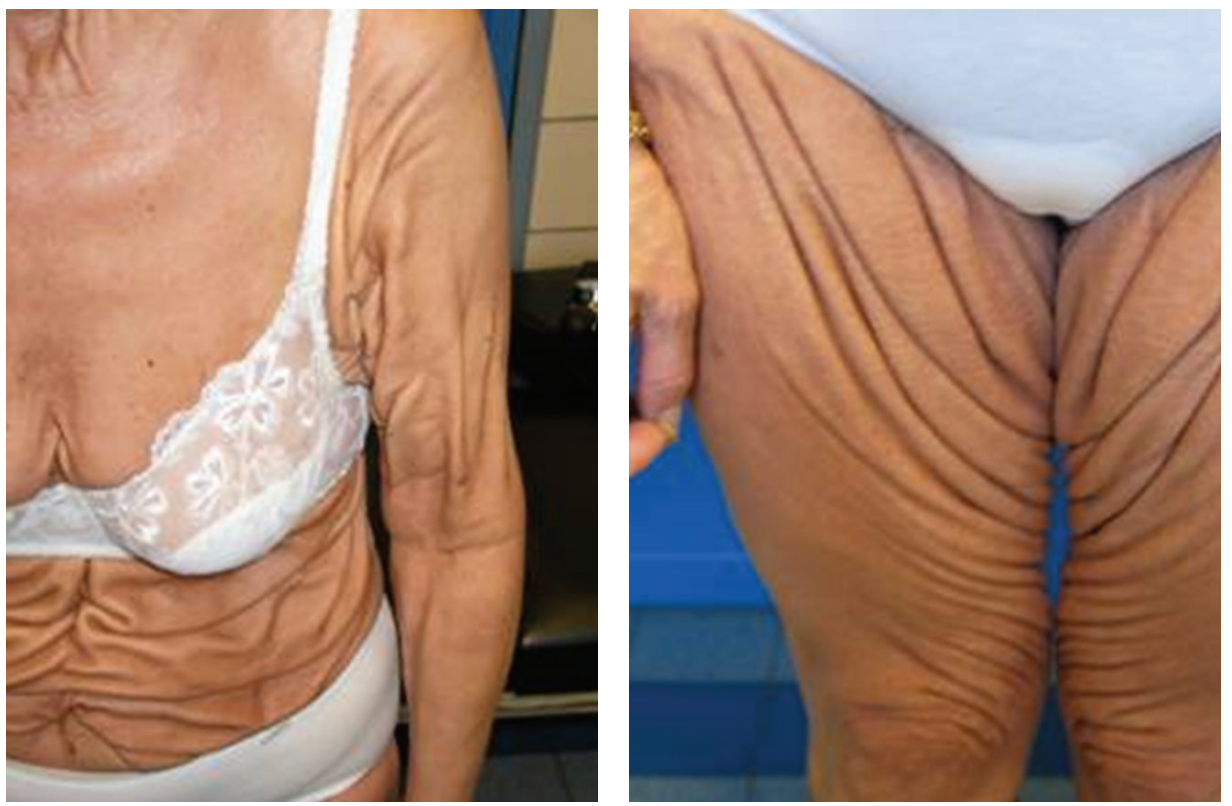

(a)

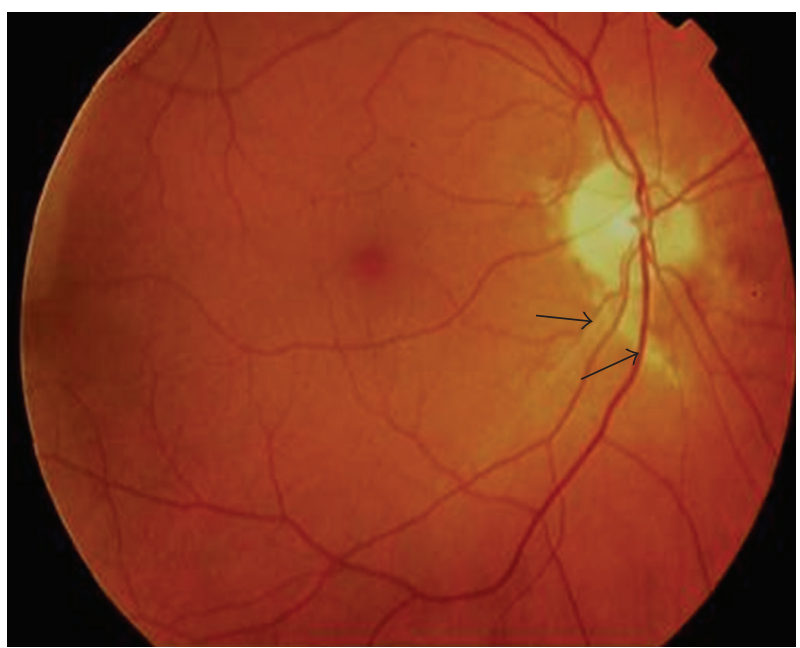

(b)

Figure 4: Clinical symptoms of the PXE-like syndrome. Severe cutis laxa-like skin folds beyond the flexural areas (a). A mild retinopathy with minimal angioid streaks (b, arrowed).

chrom. 9q22 and 3p22, resp.), altering the transmission of subcellular TGF- $\beta$ signal, mediated by increased activation of Smad2 [78]. Common clinical features include aortic and arterial aneurysms or dissections and skeletal manifestations resembling Marfan syndrome (pectus deformity, arachnodactyly, joint laxity). Seventy-five percent of patients have LDS Type I with craniofacial features including hypertelorism and cleft palate or bifid uvula (Figure 6) [78, 79]. LDS Type II resembles vascular EDS, with cutaneous manifestations such as easy bruising and atrophic scars. In contrast with Marfan syndrome, generalised arterial tortuosity and aneurysms of other arteries besides the aorta have been noted. Tortuosity was most frequently seen in head and neck vessels $[78,79]$. In LDS Type I and II, aneurysmal changes of the vertebral and head arteries were reported $[80,81]$. In LDS Type I, $11 \%$ of patients had aneurysms of arteries in the head and neck, compared to 7\% in LDS Type II [79]. Importantly, these vascular abnormalities tend to manifest at a younger age, with a more aggressive evolution which can be observed by dissection or rupture at a vessel diameter which is not predictive of such an event. This aggressive nature is also reflected in a mean age of death of LDS patients of 37 years, with cerebral bleeding as the third leading cause of demise after thoracic and abdominal aortic dissection $[78,79]$.

The diagnosis of LDS is based on the clinical characteristics and can be confirmed by mutation analysis of the TGFBR1 and TGFBR2 gene [78, 79]. As the natural history 


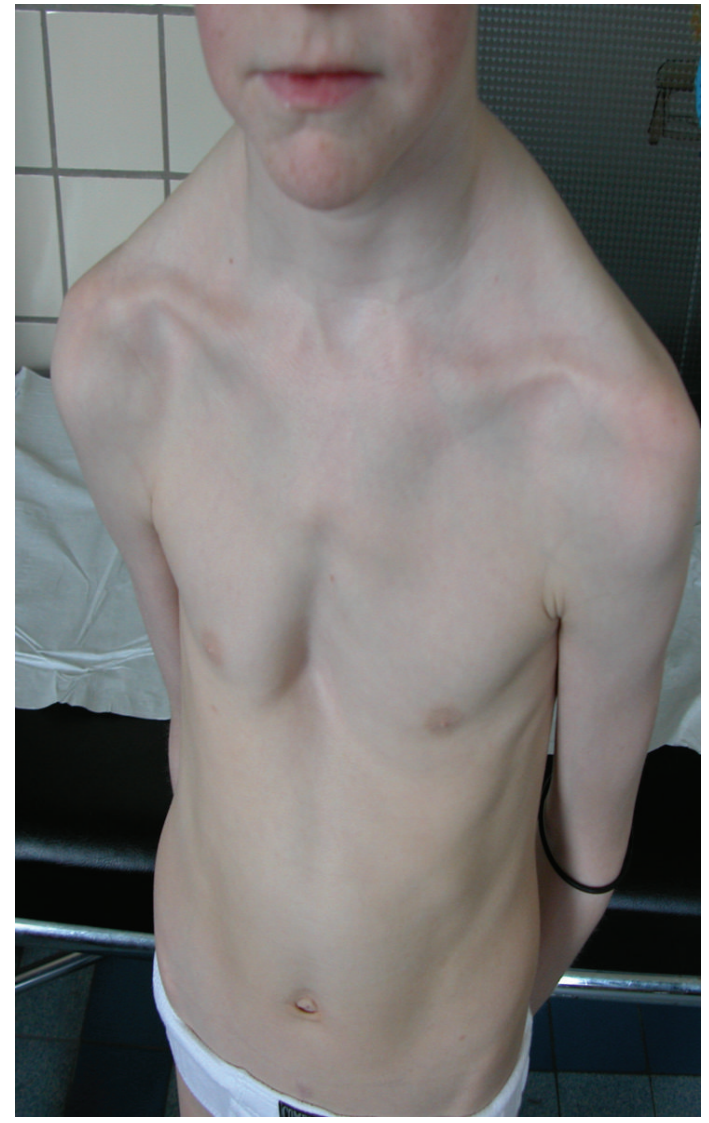

(a)

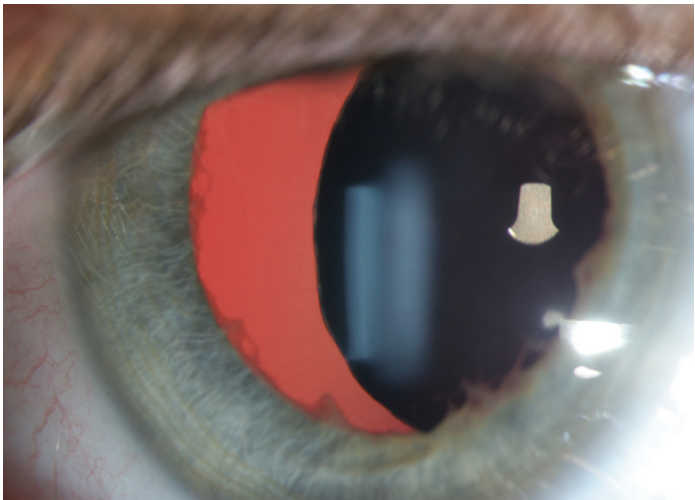

(b)

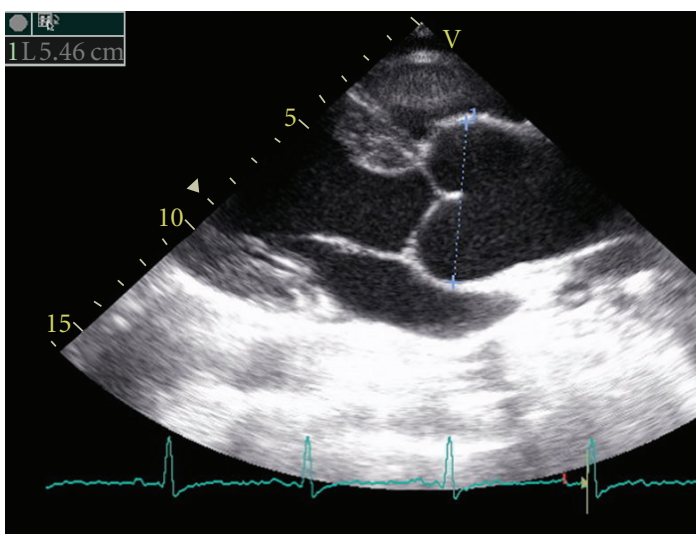

(c)

Figure 5: The Marfan syndrome. Patients present with skeletal findings such as pectus excavatum (a), lens luxation (b) and aortic root dilatation $(\mathrm{c})$.

of LDS differs from that of other CTD, management is individualised and involves measures as described for the Marfan syndrome but with an even more rigorous followup and option of surgical repair of aortic dilatation at a smaller diameter and at an earlier age compared to Marfan patients $[78,79,82]$.

3.4. Bicommisural Aortic Valve with Ascending Aortic Aneurysm. Bicommisural (bicuspid) aortic valve with ascending aortic aneurysm (BAV, OMIM\# 109730) is considered a separate entity characterised by an aortic valve with 2 rather than 3 leaflets, which can be associated with lifethreatening aneurysm or dissection of the aorta (Figure 7) $[83,84]$. It is inherited in an autosomal dominant fashion with reduced penetrance, especially in females [85]. BAV is thought to be genetically heterogeneous, with at present only one gene identified, the NOTCH1 gene, on chrom. 9q34.3 [86]. NOTCH1 is a signalling and transcription regulator which causes a spectrum of developmental nonsyndromic aortic valve anomalies and severe valve calcification [87]. BAV is a common congenital heart defect, affecting 1 to $2 \%$ of the population. Though it was a long-standing belief that the aortic changes were due to postvalvular hemodynamic changes, it has now become clear that they are primarily related to the underlying arteriopathy, thus making BAV a generalised CTD $[83,84]$.

The BAV arteriopathy does not seem to be confined to the thoracic aorta, as spontaneous dissections of the cervical and intracranial arteries have been reported [88-90]. Recently, Schievink et al. reported an increased frequency of aneurysms of the intracranial carotid and cerebral arteries among patients with $\mathrm{BAV}$, levelling up to $10 \%$ compared to $1 \%$ in controls [91].

The diagnosis of BAV is made via heart auscultation and confirmed by cross-sectional and doppler echocardiography $[83,84]$. Molecular analysis of the NOTCH1 gene may be helpful in familial screening, though BAV is undoubtedly genetic heterogeneous [85]. Management includes regular clinical followup, endocarditis prophylaxis and surgical intervention if necessary. No formal screening protocol has been established for BAV patients to evaluate the presence of intracranial aneurysms. Further studies are needed to evaluate the usefulness of sequential MRI-angiography in this patient population [92]. First degree relatives of a patient should be offered screening for BAV.

3.5. Arterial Tortuosity Syndrome. Arterial tortuosity syndrome (ATS, OMIM\# 208050) is an autosomal recessive 


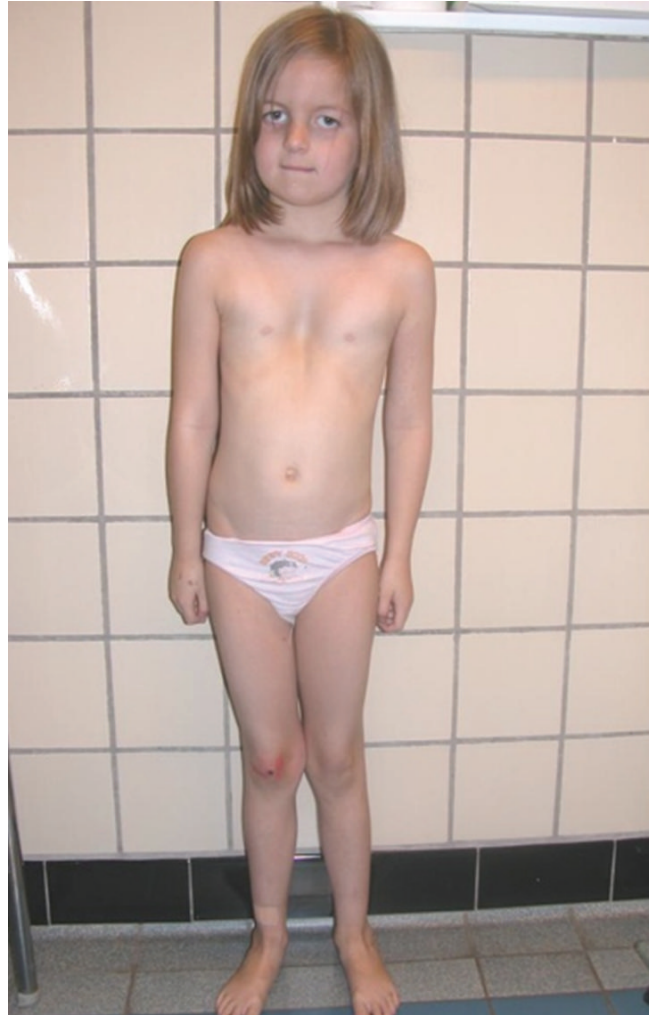

(a)

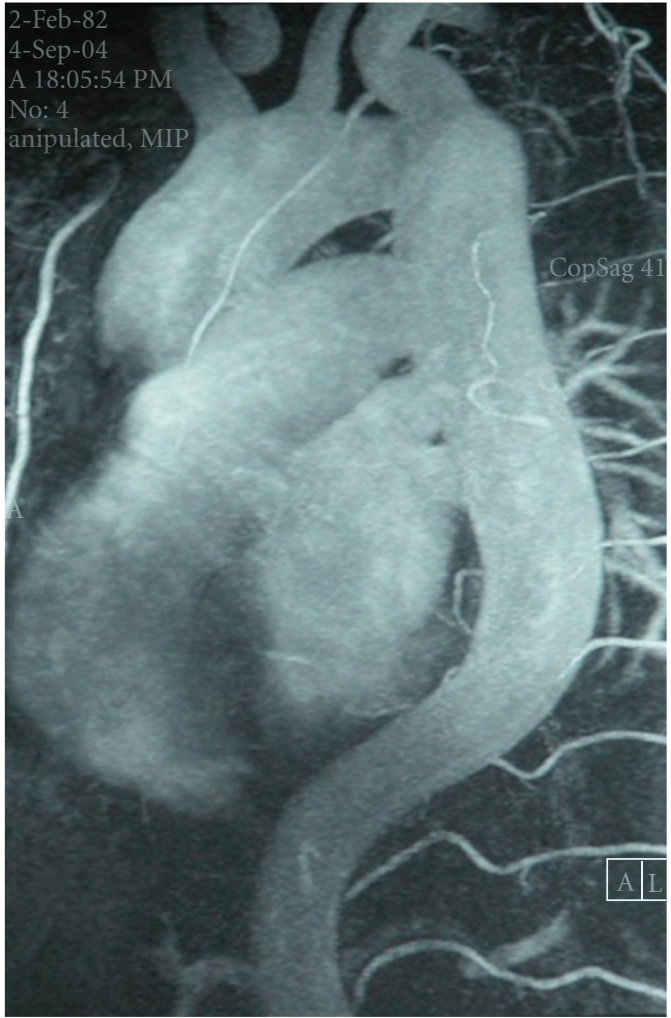

(b)

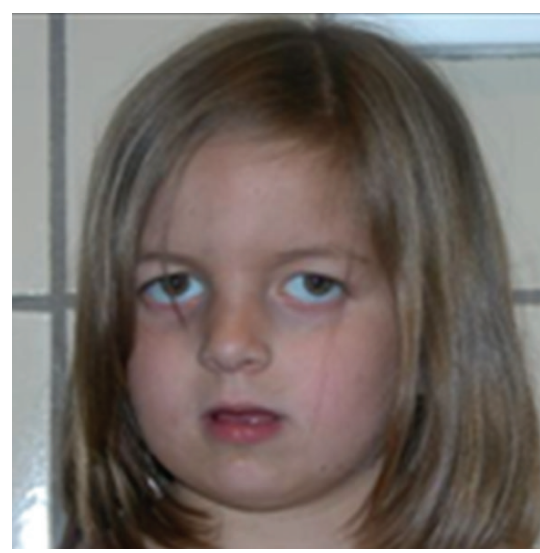

(c)

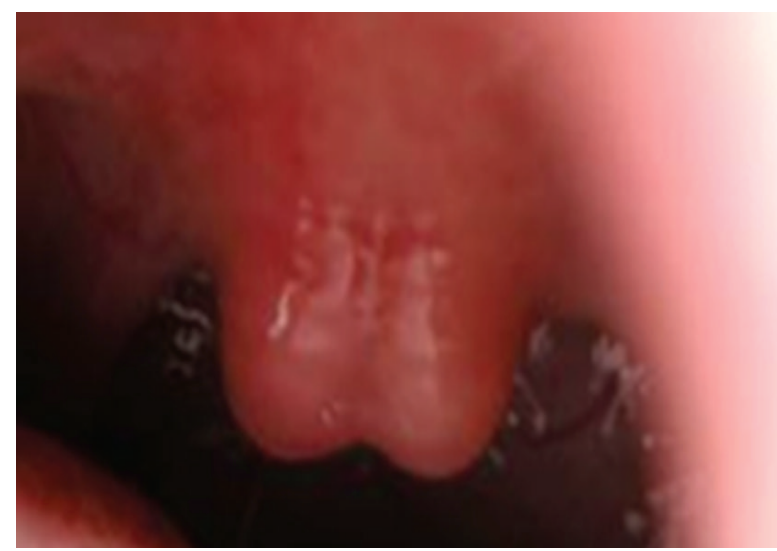

(d)

FIgURE 6: Features of the Loeys-Dietz syndrome Type I. Patients present a marfanoid habitus and hypertelorism (a, c), aortic dilatation (c) and a bifid uvula $(\mathrm{d})$.

connective tissue disorder, characterised by arachnodactyly, joint and skin laxity and widespread arterial involvement with elongation, tortuosity and aneurysm of the mediumsized and large arteries [93]. Facial characteristics include a long slender face with sagging cheeks, beaked nose, thin skin, large ears and high-arched palate (Figure 8) [93, 94]. It is caused by mutations in the SLC2A10 gene, encoding the facilitative glucose transporter GLUT10 [95]. Deficiency of GLUT10 is associated with upregulation of the TGF- $\beta$ pathway in the arterial wall, similar to LDS, resulting in disruption of elastic fibres and fragmentation of the internal elastic membrane $[95,96]$.

Ischaemic stroke has been described in four cases of ATS, all of which were in young adults. The mechanism by which ATS leads to stroke has not been established but may involve alterations of the endothelial surface leading to arterial thrombosis, arterial stenosis evolving to occlusion and infarction or dissection of an affected vessel [94, 97].

The diagnosis of ATS is made based on clinical examination and bloodvessel imaging by means of ultrasound and 


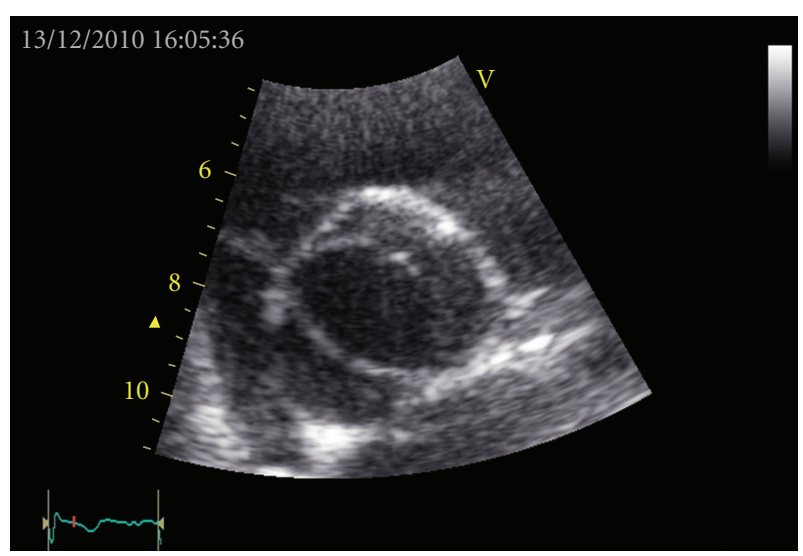

FIgURE 7: Echocardiographic image of a bicuspid aortic valve.

MRI-angiography to demonstrate arterial tortuosity. The diagnosis can then by confirmed by analysis of the SLC2A10 gene. Currently, no aetiological treatment exists for ATS and management is focussed on prevention, detection and treatment of the complications $[93,94]$.

3.6. Supravalvular Aortic Stenosis. Supravalvular aortic stenosis (SVAS, OMIM\# 185500) may occur as an autosomal dominant isolated disease or as part of a complex developmental disorder, the Williams-Beuren syndrome (WBS) $[98,99]$. Clinical and structural characteristics of SVAS are however identical in both groups. Isolated SVAS is caused by mutations in the elastin gene (ELN, chrom. 7q11.2), leading to disorganization of the lamellar architecture of the tunica media, irregular elastic fibres and smooth muscle cell hypertrophy [100]. Patients may present with dyspnoea, angina and syncope due to a variable degree of left ventricular outflow tract obstruction [98]. In addition to the aorta, other major arteries, including carotid and cerebral vessels, may also be affected by narrowing in patients with SVAS, leading to susceptibility to stroke from childhood on [101].

As part of the WBS, an autosomal dominant syndrome featuring besides the cardiovascular and connective tissue problems also neurobehavioural, facial, metabolic and growth abnormalities, it is associated with a $1.5-2 \mathrm{MB}$ microdeletion on chrom. 7q11.2 [99]. SVAS can be observed in $70 \%$ of patients. Arterial narrowing may be isolated or can occur simultaneously at different locations, including the intracranial vessels. WBS patients can suffer ischaemic stroke in the presence or absence of stenosis of the cerebral vasculature [102]. Prognosis may be compromised if intracerebral haemorrhage occurs simultaneously [103]. Besides SVAS, also hypertension due to renal artery involvement may be a contributory factor to stroke in WBS.

Diagnosis of SVAS is made on echocardiography. Treatment consists of surgical patch grafting of the stenotic region of the aorta. Less invasive procedures, such as balloon angioplasty or stenting, have been successful but carry a higher risk for rupture, aneurysm or restenosis [99].

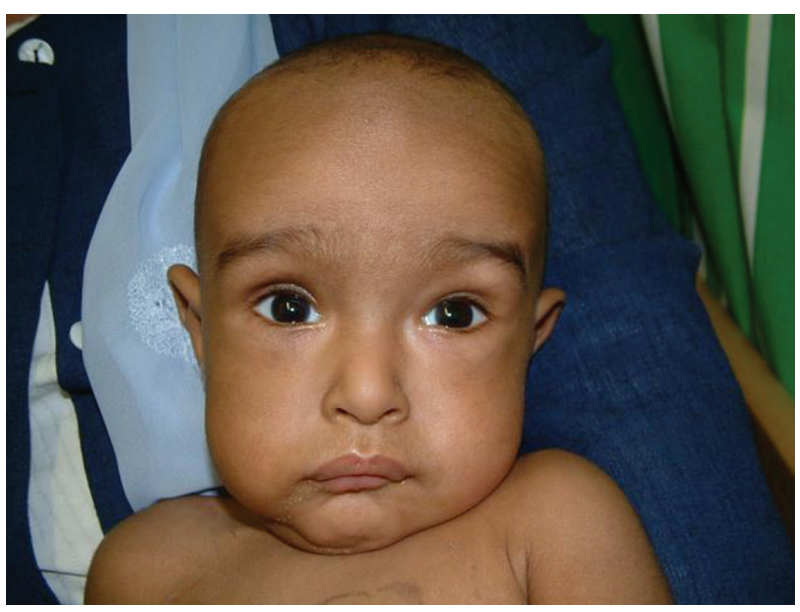

(a)

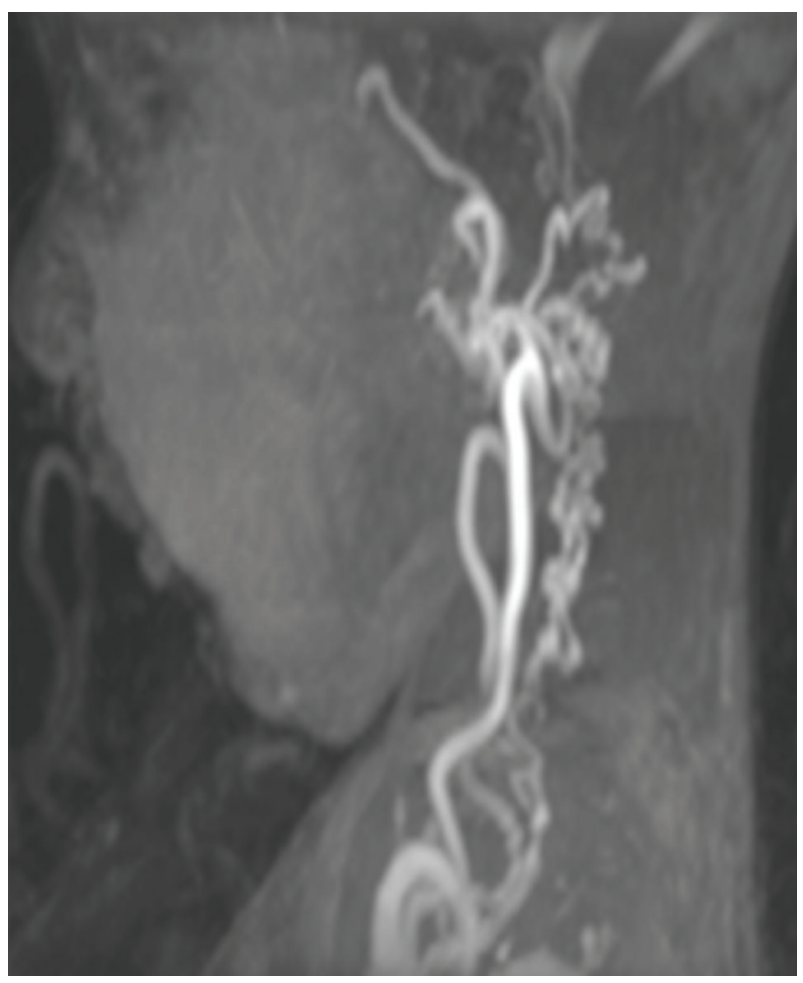

(b)

Figure 8: Patient characteristics of the Arterial Tortuosity Syndrome. Longslender face with sagging cheeks and large ears (a). Marked arterial tortuosity (b).

\section{Disorders with Generalised Connective Tissue Involvement}

4.1. Spontaneous Cervical Artery Dissection. Spontaneous cervical artery dissection (SCAD, OMIM\# 147820) is an important cause of ischaemic stroke in young patients [104]. Though some CTD, such as osteogenesis imperfecta or the classical and vascular form of EDS, predispose for SCAD, most patients do not feature other symptoms of CTD [105-107]. Still, ultrastructural analysis revealed mild but 
reproducible disruption of connective tissue morphology, with involvement of either collagen or elastic fibres or both [108]. Its pathogenesis being unclear, several candidate genes and loci have been proposed, many of which are involved in the biosynthesis of the ECM. However, several genes involved in important CTD, such as COL3A1, COL5A1, COL5A2 and ABCC6 have been excluded in sporadic SCAD patients [109112]. Large studies, such as the European CADISP (Cervical Artery Dissection and Ischaemic Stroke Patients) study, are currently ongoing to unravel the genetic background of SCAD [113].

In a minority of patients, a positive familial history is present, suggesting an autosomal dominant inheritance pattern $[114,115]$. As most patients do not have such a family history, it is proposed that the penetrance of the genetic predisposition of SCAD is low, meaning that the connective tissue aberration is not a sufficient cause for SCAD. Other constitutional and environmental factors which have been identified in SCAD patients and may influence the phenotype include infection and mild hyperhomocysteinemia [116].

The diagnosis of SCAD being a clinical one, the probable heterogeneous genetic aetiology of the disorder does not allow specific diagnostic molecular analysis in patients at this time if classic CTD such as EDS, OI or Marfan syndrome have been clinically excluded [117]. It must be noted though that associated CTD symptoms can be very mild, emphasizing the importance of a thorough clinical history and examination.

4.2. Hereditary Haemorrhagic Telangiectasia. Hereditary haemorrhagic telangiectasia (HHT, Rendu-Osler-Weber syndrome, OMIM\# 187300) is an autosomal dominant vascular dysplasia described as the triad of mucocutaneous telangiectases, recurrent epistaxis or gastrointestinal haemorrhage and a family history of the disorder (Figure 9) [118]. Visceral involvement, the fourth clinical criterion, includes that of the lung, liver and brain [118]. Most patients exhibit symptoms by the age of 40 . The pathogenesis of the arteriovenous malformations in HHT includes dilatation of postcapillary venules which enlarge and connect through capillaries with dilated arterioles. With increase in size, the capillary segments disappear and an AV communication is formed [118].

HHT is caused by mutations in the ENG and ALK1 gene (chrom. 9q34.1 and 12q11-q14), encoding endoglin and Activin A receptor Type II-like 1, respectively, [119, 120]. Other genetic loci for HHT have been reported, indicating genetic heterogeneity [121]. Endoglin is a TGF- $\beta$ binding protein and causes HHT1, which is associated with an earlier onset of epistaxis and telangiectasias. ALK1-associated HHT (HHT2), caused by disruption of the Type I cell-surface receptor for the TGF- $\beta$ superfamily of ligands, features later onset and more hepatic involvement compared to HHT1 $[120,121]$.

Cerebral and spinal complications of HHT include telangiectases, arteriovenous malformations and carotidcavernous fistulas [122]. Moreover, HHT patients are prone

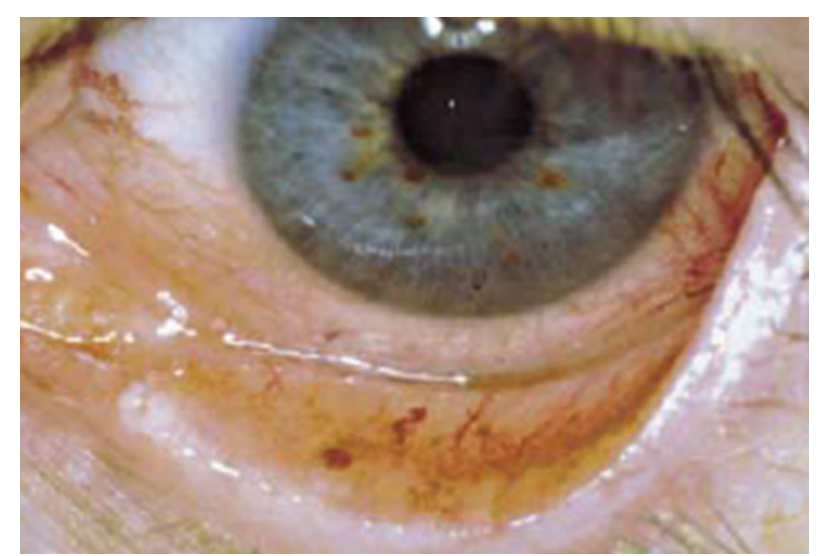

FIGURE 9: Telangiectasias on the inner side of the lower eyelid in a HHT patient.

to pulmonary arteriovenous fistulae, responsible for paradoxical embolism resulting in stroke or transient ischaemic attack [123]. Cerebral haemorrhage in HHT patients usually has a devastating effect [122].

The diagnosis of HHT is based on the presence of the above mentioned criteria and can be made if at least 3 criteria are present [118]. Molecular analysis of the ENG and ALK1 genes can confirm the diagnosis and allows familial screening and counselling. In this respect, it is important to recognize that children of a patient cannot be reassured of not having HHT without negative molecular analysis as symptoms most often only occur in the second or third decade of life. Molecular testing in such young individuals, who are not able to give consent, remains however controversial. A similar controversy exists about the screening of asymptomatic individuals for cerebral arteriovenous malformations, though it is recommended in some countries due to the devastating effects of a cerebral bleeding.

Management of HHT can consist of therapy with bevacizumab, an antiVEGF antibody of which several successful reports were published [124]. Other treatments, including estrogen or antifibrinolytic therapy, have inconsistent results. Importantly, all patients should be screened for pulmonary arteriovenous fistulae. No optimal screening protocol has been established but should include chest radiography and contrast echocardiogram. Depending on the results, this can be complemented with CT scan of the chest or pulmonary angiography $[125,126]$.

4.3. Fibromuscular Dysplasia. Fibromuscular dysplasia (FMD, OMIM\# 135580) is an autosomal dominant noninflammatory, nonatherosclerotic segmental disease of the arteries, occurring in young to middle-aged individuals [127]. While renal arteries are most commonly affected, resulting in hypertension, other large vessels including carotid and vertebral arteries may be involved [128, 129]. The origin of FMD remains currently largely unknown, with speculation of a collagen disorder, congenital aetiology and inflammatory origin. Thus far, no unequivocally associated genes have been discovered [127]. 
TABLE 3: Summary of the most important connective tissue diseases related to stroke in young adults.

\begin{tabular}{|c|c|c|c|}
\hline Disease & Inherit. & Diagnosis & Phenotype \\
\hline $\begin{array}{l}\text { Vascular Ehlers-Danlos } \\
\text { syndrome }\end{array}$ & $\mathrm{AD}$ & $\begin{array}{l}\text { Biochemical analysis (skin biopsy) } \\
\text { COL3A1 analysis (fibroblasts) }\end{array}$ & $\begin{array}{l}\text { Facial gestalt (thin nose and lips, sunken cheeks), skin fragility, } \\
\text { extreme vascular fragility, rupture of uterus and colon } \\
\text { Intracerebral aneurysm, carotid/vertebral dissection }\end{array}$ \\
\hline $\begin{array}{l}\text { Type } 4 \text { collagen-related } \\
\text { small vessel disease }\end{array}$ & $\mathrm{AD}$ & COL4A1 analysis (blood sample) & $\begin{array}{l}\text { Infantile hemiparesis, seizures, migraine, retinal artery } \\
\text { tortuosity, renal and muscular involvement } \\
\text { Small vessel ischaemic stroke or haemorrhage }\end{array}$ \\
\hline HANAC syndrome & $\mathrm{AD}$ & $\begin{array}{l}\text { Skin biopsy } \\
\text { COL4A1 analysis (blood sample) }\end{array}$ & $\begin{array}{l}\text { Hereditary angiopathy with retinal artery tortuosity, cystic } \\
\text { renal disease, cerebral aneurysm, muscle cramps }\end{array}$ \\
\hline Osteogenesis imperfecta & $\begin{array}{l}\mathrm{AD} \\
\mathrm{AR}\end{array}$ & $\begin{array}{l}\text { Radiological examination } \\
\text { Biochemical analysis (skin biopsy) } \\
\text { Molecular analysis of OI genes } \\
\text { (fibroblasts and blood sample) }\end{array}$ & $\begin{array}{l}\text { Fractures, osteopenia, bone deformities, hearing loss, blue } \\
\text { sclerae, dentinogenesis imperfecta } \\
\text { Intracerebral aneurysm, moyamoya-like disease, } \\
\text { carotid/vertebral dissection }\end{array}$ \\
\hline $\mathrm{AD}$ polycystic kidneys & $\mathrm{AD}$ & $\begin{array}{l}\text { Renal ultrasonography } \\
\text { PKD1/2 linkage analysis (blood) } \\
\text { PKD1/2 molecular analysis (blood) }\end{array}$ & $\begin{array}{l}\text { Bilateral renal cysts, liver and pancreas cysts, aortic } \\
\text { dilatation/dissection } \\
\text { Intracranial aneurysm }\end{array}$ \\
\hline $\begin{array}{l}\text { Pseudoxanthoma } \\
\text { elasticum }\end{array}$ & $\mathrm{AR}$ & $\begin{array}{l}\text { Skin biopsy } \\
\text { ABCC6 analysis (blood sample) }\end{array}$ & $\begin{array}{l}\text { Yellowish skin papules in flexural areas, retinopathy, coronary } \\
\text { and peripheral artery disease } \\
\text { Ischaemic stroke in patients and heterozygous carriers }\end{array}$ \\
\hline PXE-like syndrome & $\mathrm{AR}$ & $\begin{array}{l}\text { Coagulation testing } \\
\text { Skin biopsy } \\
\text { GGCX analysis (blood sample) }\end{array}$ & $\begin{array}{l}\text { Generalized cutis laxa, mild retinopathy, coagulation disorder } \\
\text { Cerebral aneurysm? }\end{array}$ \\
\hline Marfan syndrome & $\mathrm{AD}$ & $\begin{array}{l}\text { Revised Ghent Nosology } \\
\text { Fibrillin } 1 \text { analysis (blood sample) }\end{array}$ & $\begin{array}{l}\text { Tall stature, arachnodactyly, pectus deformity, ectopia lentis, } \\
\text { aortic root dilatation } \\
\text { Carotid artery dissection, cerebral and spinal cord infarction }\end{array}$ \\
\hline $\begin{array}{l}\text { Loeys-Dietz syndrome } \\
\text { Type I }\end{array}$ & $\mathrm{AD}$ & $\begin{array}{l}\text { TGFBR } 1 \text { and } 2 \text { analysis (blood } \\
\text { sample) }\end{array}$ & $\begin{array}{l}\text { Marfanoid habitus, hypertelorism, cleft palate, bifid uvula, } \\
\text { generalized arterial tortuosity and aneurysms } \\
\text { intracranial aneurysm, carotid and vertebral aneurysm }\end{array}$ \\
\hline $\begin{array}{l}\text { Loeys-Dietz syndrome } \\
\text { Type II }\end{array}$ & $\mathrm{AD}$ & $\begin{array}{l}\text { TGFBR } 1 \text { and } 2 \text { analysis (blood } \\
\text { sample) }\end{array}$ & $\begin{array}{l}\text { Vascular EDS-like phenotype, generalized arterial tortuosity } \\
\text { and aneurysms } \\
\text { intracranial aneurysm, carotid and vertebral aneurysm }\end{array}$ \\
\hline Bicuspid aortic valve & $\mathrm{AD}$ & $\begin{array}{l}\text { Echocardiography } \\
\text { NOTCH1 gene in familial cases } \\
\text { (blood sample) }\end{array}$ & $\begin{array}{l}\text { Bicuspid aortic valve on ultrasound } \\
\text { Dissection of carotid and cerebral arteries, intracranial aneurysm }\end{array}$ \\
\hline $\begin{array}{l}\text { Arterial tortuosity } \\
\text { syndrome }\end{array}$ & $\mathrm{AR}$ & SLC2A10 analysis (blood sample) & $\begin{array}{l}\text { Facial dysmorphism, arachnodactyly, joint and skin laxity, } \\
\text { arterial elongation, tortuosity and aneurysms } \\
\text { Ischaemic stroke? }\end{array}$ \\
\hline $\begin{array}{l}\text { Supravalvular aortic } \\
\text { stenosis }\end{array}$ & $\mathrm{AD}$ & ELN analysis (blood sample) & $\begin{array}{l}\text { Left ventricular outflow obstruction } \\
\text { Ischaemic stroke }\end{array}$ \\
\hline $\begin{array}{l}\text { Williams-Beuren } \\
\text { syndrome }\end{array}$ & $\mathrm{AD}$ & FISH or microarray & $\begin{array}{l}\text { SVAS, facial dysmorphism, short stature } \\
\text { Ischaemic stroke, intracerebral haemorrhage }\end{array}$ \\
\hline $\begin{array}{l}\text { Spontaneous cervical } \\
\text { artery dissection }\end{array}$ & $\mathrm{AD}$ & Clinical examination & $\begin{array}{l}\text { Exclude vascular EDS, Marfan syndrome and osteogenesis } \\
\text { imperfecta }\end{array}$ \\
\hline $\begin{array}{l}\text { Hereditary } \\
\text { haemorrhagic } \\
\text { telangiectasia }\end{array}$ & $\mathrm{AD}$ & $\begin{array}{l}\text { Clinical evaluation } \\
\text { ENG and ALK1 analysis (blood } \\
\text { sample) }\end{array}$ & $\begin{array}{l}\text { Mucocutaneous telangiectases, epistaxis, gastrointestinal } \\
\text { haemorrhage } \\
\text { Cerebral/spinal telangiectases, carotid-carvernous fistulas, } \\
\text { ischaemic stroke or TIA, cerebral haemorrhage }\end{array}$ \\
\hline Fibromuscular dysplasia & $\mathrm{AD}$ & $\begin{array}{l}\text { Doppler ultrasound and } \\
\text { angiography }\end{array}$ & $\begin{array}{l}\text { String of beads in affected vascular beds } \\
\text { TIA and ischaemic stroke, cervicocranial dissection, intracerebral } \\
\text { aneurysm }\end{array}$ \\
\hline
\end{tabular}

Cerebrovascular phenotypes are indicated in italics. AD: autosomal dominant; AR: autosomal recessive.

Neurological implications of FMD include TIA and stroke, resulting from occlusion, arterial dissection of cervicocranial vessels or subarachnoid haemorrhage due to ruptured aneurysm [129-135]. The latter may be more likely when there is also renal involvement, due to the hypertension. Particularly the association of haemorrhage due to aneurysm rupture and ischaemic stroke due to stenosis in a given patient is characteristic of cerebral FMD.

Diagnosis of FMD is made based on clinical history, doppler ultrasound and angiography, via which the typical 
image of "string of beads" can be seen [127]. Treatment may imply either surgical correction with resection of the diseased vessel portion or stenting by a vascular radiologist. The success of these treatments depends largely on the early detection of the disease $[127,136]$.

\section{Candidate Extracellular Matrix Genes}

Besides the distinct connective tissue disorders described above, some ECM proteins playing an essential role in connective tissue homeostasis have been suggested to be implicated in haemorrhagic or ischaemic stroke. As the ECM contains over 2500 proteins, the summary below is not limitative and several other ECM constituents are likely to be involved in stroke, either leading to a well-defined phenotype or as a more general risk factor.

5.1. Stromelysin. Stromelysin-1 or MMP3 is a member of the matrix metalloproteinase (MMP) family, regulating the accumulation of ECM. Recently, an association was found in Italian ischaemic stroke patients who were homozygous for a common promotor variant (genotype $5 \mathrm{~A} / 5 \mathrm{~A}$ ), in which both alleles have a run of 5 adenosines [137]. This finding was inconsistent with in vitro studies which showed a promotor variant with a run of 6 adenosines to be associated with a higher IMT and warrants further study [138].

5.2. Versican. Versican is a proteoglycan playing an important role in ECM assembly. The gene encoding versican, CSPG2 (chrom. 5q) is located in a genomic region reported to be associated with intracranial aneurysms. Ruigrok et al. suggested that SNPs around and in the versican gene play a role in the susceptibility of intracranial aneurysms, which was confirmed in a second, larger study $[139,140]$. It is currently unclear though to what extent these basepair changes are causal for the aneurysms.

5.3. Perlecan. Perlecan (heparansulfateproteoglycan) is a major component of basement membranes, encoded by the HSPG gene (chrom. 1p36.1). Like versican, it is also located in a region reported to be associated with intracranial aneurysms. HSPG SNPs were recently shown to be mildly associated with intracranial aneurysms; the exact nature of this pathogenetic link needs to be further clarified [139].

5.4. 92 kDA Type IV Collagenase. $92 \mathrm{kDA}$ Type IV collagenase or MMP9 is an enzyme, encoded by the MMP9 gene (chrom. 20q11.2-q13.1) that degrades Type IV and V collagens. It has been shown that collagenolysis plays an important role in aneurysmal rupture, whereas elastinolysis is pertinent to vessel dilatation [141]. An MMP9 polymorphism associated with higher promotor activity has been shown to occur at a higher frequency in patients with intracranial haemorrhage, though a second independent study was not able to confirm this relation [142, 143]. MMP9 has also been implicated in haemorrhages following intravenous thrombolysis and haemorrhagic transformation of ischaemic stroke [144]. Further studies are needed to test these associations.

\section{Conclusion}

The objective of this paper was to bring to attention several connective tissue disorders which can be related to ischaemic and/or haemorrhagic stroke in young adults (Table 3). While some are more prevalent than others, it should be emphasized that the severity of the clinical spectrum of many of these disorders is highly variable. This probably leads to underdiagnosis, a phenomenon which has been clearly established for some CTD, such as PXE. In this respect, the importance of a well-oriented clinical history and examination as well as a good familial history should be emphasized, as often only the combination of all these data will raise suspicion of an underlying connective tissue cause. As many of these disorders have important implications, in first instance for the patient but also for his relatives, recognition of CTD as a cause for stroke is no longer an academic issue but an essential part of the stroke aetiological evaluation in children and young adults. Though molecular testing is already available for several of these disorders, it can be foreseen that many more ECM constituents and other proteins involved directly or indirectly in connective tissue homeostasis will be identified as a cause of or risk factor for stroke in the young.

\section{References}

[1] R. L. Sacco, J. H. Ellenberg, J. P. Mohr et al., "Infarcts of undetermined cause: the NINCDS Stroke Data Bank," Annals of Neurology, vol. 25, no. 4, pp. 382-390, 1989.

[2] A. Orlacchio and G. Bernardi, "Research actuality in the genetics of stroke," Clinical and Experimental Hypertension, vol. 28, no. 3-4, pp. 191-197, 2006.

[3] A. Hassan and H. S. Markus, "Genetics and ischaemic stroke," Brain, vol. 123, no. 9, pp. 1784-1812, 2000.

[4] L. Morgan and S. E. Humphries, "The genetics of stroke," Current Opinion in Lipidology, vol. 16, no. 2, pp. 193-199, 2005.

[5] J. Myllyharju and K. I. Kivirikko, "Collagens and collagenrelated diseases," Annals of Medicine, vol. 33, no. 1, pp. 7-21, 2001.

[6] D. M. Milewicz, Z. Urbán, and C. Boyd, "Genetic disorders of the elastic fiber system," Matrix Biology, vol. 19, no. 6, pp. 471-480, 2000.

[7] M. Czarny-Ratajczak and A. Latos-Bieleńska, "Collagens, the basic proteins of the human body," Journal of Applied Genetics, vol. 41, no. 4, pp. 317-330, 2000.

[8] P. Beighton, A. De Paepe, B. Steinmann, P. Tsipouras, and R. J. Wenstrup, "Ehlers-danlos syndromes: revised nosology," American Journal of Medical Genetics, vol. 77, no. 1, pp. 3137, 1998.

[9] P. Beighton, A. De Paepe, J. G. Hall et al., "Molecular nosology of heritable disorders of connective tissue," American Journal of Medical Genetics, vol. 42, no. 4, pp. 431-448, 1992.

[10] G. S. Oderich, J. M. Panneton, T. C. Bower et al., "The spectrum, management and clinical outcome of EhlersDanlos syndrome type IV: a 30-year experience," Journal of Vascular Surgery, vol. 42, no. 1, pp. 98-106, 2005.

[11] S. Savasta, P. Merli, M. Ruggieri, L. Bianchi, and M. V. Spartà, "Ehlers-Danlos syndrome andneurological features: a review," Child's Nervous System. In press. 
[12] K. N. North, D. A. H. Whiteman, M. G. Pepin, and P. H. Byers, "Cerebrovascular complications in Ehlers-Danlos syndrome type IV," Annals of Neurology, vol. 38, no. 6, pp. 960-964, 1995.

[13] W. I. Schievink, M. Limburg, J. W. E. Oorthuys, P. Fleury, and F. M. Pope, "Cerebrovascular disease in Ehlers-Danlos syndrome type IV," Stroke, vol. 21, no. 4, pp. 626-632, 1990.

[14] A. Edwards and G. W. Taylor, "Ehlers-Danlos syndrome with vertebral artery aneurysm," Proceedings of the Royal Society of Medicine, vol. 62, no. 7, pp. 734-735, 1969.

[15] F. H. Mirza, P. L. Smith, and W. N. Lim, "Multiple aneurysms in a patient with Ehlers-Danlos syndrome: angiography without sequelae," American Journal of Roentgenology, vol. 132, no. 6, pp. 993-995, 1979.

[16] M. Pepin, U. Schwarze, A. Superti-Furga, and P. H. Byers, "Clinical and genetic features of Ehlers-Danlos syndrome type IV, the vascular type," New England Journal of Medicine, vol. 342, no. 10, pp. 673-680, 2000.

[17] M. K. RUBINSTEIN and N. H. COHEN, "Ehlers-Danlos syndrome associated with multiple intracranial aneurysms," Neurology, vol. 14, pp. 125-132, 1964.

[18] A. Schoolman and J. J. Kepes, "Bilateral spontaneous carotidcavernous fistulae in Ehlers-Danlos syndrome. Case report," Journal of Neurosurgery, vol. 26, no. 1, pp. 82-86, 1967.

[19] P. Forlodou, A. De Kersaint-Gilly, J. Pizzanelli, M. P. Viarouge, and E. Auffray-Calvier, "Ehlers-Danlos syndrome with a spontaneous caroticocavernous fistula occluded by detachable balloon: case report and review of literature," Neuroradiology, vol. 38, no. 6, pp. 595-597, 1996.

[20] H. A. Desal, F. Toulgoat, S. Raoul et al., "Ehlers-Danlos syndrome type IV and recurrent carotid-cavernous fistula: review of the literature, endovascular approach, technique and difficulties," Neuroradiology, vol. 47, no. 4, pp. 300-304, 2005.

[21] M. H. Less, V. D. Menashe, C. O. Sunderland, C. L. Morgan, and P. J. Dawson, "Ehlers-Danlos syndrome associated with multiple pulmonary artery stenoses and tortuous systemic arteries," The Journal of Pediatrics, vol. 75, no. 6, pp. 10311036, 1969.

[22] S. Sultan, M. Morasch, M. P. Colgan, P. Madhavan, D. Moore, and G. Shanik, "Operative and endovascular management of extracranial vertebral artery aneurysm in Ehlers-Danlos syndrome: a clinical dilemma-case report and literature review," Vascular and Endovascular Surgery, vol. 36, no. 5, pp. 389-392, 2002.

[23] S. G. Mattar, A. G. Kumar, and A. B. Lumsden, "Vascular complications in Ehlers-Danlos syndrome," American Surgeon, vol. 60, no. 11, pp. 827-831, 1994.

[24] B. G. Hudson, S. T. Reeders, and K. Tryggvason, "Type IV collagen: structure, gene organization, and role in human diseases. Molecular basis of goodpasture and alport syndromes and diffuse leiomyomatosis," Journal of Biological Chemistry, vol. 268, no. 35, pp. 26033-26036, 1993.

[25] D. B. Gould, F. C. Phalan, G. J. Breedveld et al., "Mutations in Col4al cause perinatal cerebral hemorrhage and porencephaly," Science, vol. 308, no. 5725, pp. 1167-1171, 2005.

[26] K. Vahedi, P. Massin, J. P. Guichard et al., "Hereditary infantile hemiparesis, retinal arteriolar tortuosity, and leukoencephalopathy," Neurology, vol. 60, no. 1, pp. 57-63, 2003.

[27] D. B. Gould, F. C. Phalan, S. E. Van Mil et al., "Role of COL4A1 in small-vessel disease and hemorrhagic stroke," New England Journal of Medicine, vol. 354, no. 14, pp. 14891496, 2006.
[28] S. Lanfranconi and H. S. Markus, "COL4A1 mutations as a monogenic cause of cerebral small vessel disease: a systematic review," Stroke, vol. 41, pp. e513-e518, 2010.

[29] S. Shah, Y. Kumar, B. McLean et al., "A dominantly inherited mutation in collagen IV A1 (COL4A1) causing childhood onset stroke without porencephaly," European Journal of Paediatric Neurology, vol. 14, no. 2, pp. 182-187, 2010.

[30] K. Vahedi, N. Kubis, M. Boukobza et al., "COL4A1 mutation in a patient with sporadic, recurrent intracerebral hemorrhage," Stroke, vol. 38, no. 5, pp. 1461-1464, 2007.

[31] K. Vahedi, P. Massin, J. P. Guichard et al., "Hereditary infantile hemiparesis, retinal arteriolar tortuosity, and leukoencephalopathy," Neurology, vol. 60, no. 1, pp. 57-63, 2003.

[32] E. Plaisier, O. Gribouval, S. Alamowitch et al., "COL4A1 mutations and hereditary angiopathy, nephropathy, aneurysms, and muscle cramps," New England Journal of Medicine, vol. 357, no. 26, pp. 2687-2695, 2007.

[33] S. Alamowitch, E. Plaisier, P. Favrole et al., "Cerebrovascular disease related to COL4A1 mutations in HANAC syndrome," Neurology, vol. 73, no. 22, pp. 1873-1882, 2009.

[34] F. Rauch and F. H. Glorieux, "Osteogenesis imperfecta," The Lancet, vol. 363, no. 9418, pp. 1377-1385, 2004.

[35] P. H. Byers and W. J. Cole, "Osteogenesis imperfecta," in Connective Tissue and Its Heritable Disorders: Molecular, Genetic and Medical Aspects, P. Royce and B. Steinmann, Eds., pp. 385-430, Wiley-liss, New York, NY, USA, 1979.

[36] D. O. Silence, "Osteogenesis imperfecta: clinical variability and clas-sification," in Symposium on Heritable Disease of Connective Tissue, W. H. Akeson, P. Bornstein, and M. J. Glimcher, Eds., pp. 223-247, Mosby, St. Louis, Mo, USA, 1982.

[37] A. Gajko-Galicka, "Mutations in type I collagen genes resulting in osteogenesis imperfecta in humans," Acta Biochimica Polonica, vol. 49, no. 2, pp. 433-441, 2002.

[38] W. A. Cabral, W. Chang, A. M. Barnes et al., "Prolyl 3hydroxylase 1 deficiency causes a recessive metabolic bone disorder resembling lethal/severe osteogenesis imperfecta," Nature Genetics, vol. 39, no. 3, pp. 359-365, 2007.

[39] R. Morello, T. K. Bertin, Y. Chen et al., "CRTAP is required for prolyl 3-hydroxylation and mutations cause recessive osteogenesis imperfecta," Cell, vol. 127, no. 2, pp. 291-304, 2006.

[40] M. C. Willing, S. P. Deschenes, R. L. Slayton, and E. J. Roberts, "Premature chain termination is a unifying mechanism for COL1A1 null alleles in osteogenesis imperfecta type I cell strains," American Journal of Human Genetics, vol. 59, no. 4, pp. 799-809, 1996.

[41] S. Mundlos, D. Chan, YI. M. Weng, D. O. Sillence, W. G. Cole, and J. F. Bateman, "Multiexon deletions in the type I collagen COL1A2 gene in osteogenesis imperfecta type IB. Molecules containing the shortened $\alpha 2(\mathrm{I})$ chains show differential incorporation into the bone and skin extracellular matrix," Journal of Biological Chemistry, vol. 271, no. 35, pp. 2106821074, 1996.

[42] Z. Verkh, M. Russell, and C. A. Miller, "Osteogenesis imperfecta type II: microvascular changes in the CNS," Clinical Neuropathology, vol. 14, no. 3, pp. 154-158, 1995.

[43] S. Albayram, O. Kizilkic, H. Yilmaz, B. Tuysuz, N. Kocer, and C. Islak, "Abnormalities in the cerebral arterial system in osteogenesis imperfecta," American Journal of Neuroradiology, vol. 24, no. 4, pp. 748-750, 2003.

[44] W. I. Schievink, V. V. Michels, and D. G. Piepgras, "Neurovascular manifestations of heritable connective tissue disorders: a review," Stroke, vol. 25, no. 4, pp. 889-903, 1994. 
[45] S. Rouvière, R. Michelini, P. Sarda, and M. Pagès, "Spontaneous carotid artery dissection in two siblings with osteogenesis imperfecta," Cerebrovascular Diseases, vol. 17, no. 2-3, pp. 270-272, 2004.

[46] F. Rauch and F. H. Glorieux, "Bisphosphonate treatment in osteogenesis imperfecta: which drug, for whom, for how long?" Annals of Medicine, vol. 37, no. 4, pp. 295-302, 2005.

[47] V. E. Torres, P. C. Harris, and Y. Pirson, "Autosomal dominant polycystic kidney disease," The Lancet, vol. 369, no. 9569, pp. 1287-1301, 2007.

[48] A. U. I. Haque and A. Moatasim, "Adult polycystic kidney disease: a disorder of connective tissue?" International Journal of Clinical and Experimental Pathology, vol. 1, pp. 84-90, 2008.

[49] N. Hateboer, M. A.V. Dijk, N. Bogdanova et al., "Comparison of phonotypes of polycystic kidney disease types 1 and 2," The Lancet, vol. 353, no. 9147, pp. 103-107, 1999.

[50] C. Deltas, "Cystic diseases of the kidney molecular biology and genetics," Archives of Pathology and Laboratory Medicine, vol. 134, no. 4, pp. 569-582, 2010.

[51] Y. Pirson, D. Chauveau, and V. Torres, "Management of cerebral aneurysms in autosomal dominant polycystic kidney disease," Journal of the American Society of Nephrology, vol. 13, no. 1, pp. 269-276, 2002.

[52] M. M. Belz, G. M. Fick-Brosnahan, R. L. Hughes et al., "Recurrence of intracranial aneurysms in autosomaldominant polycystic kidney disease," Kidney International, vol. 63 , no. 5, pp. 1824-1830, 2003.

[53] T. Inagawa, "Trends in incidence and case fatality rates of aneurysmal subarachnoid hemorrhage in Izumo City, Japan, between 1980-1989 and 1990-1998," Stroke, vol. 32, no. 7, pp. 1499-1507, 2001.

[54] Y. Pei and T. Watnick, "Diagnosis and screening of autosomal dominant polycystic kidney disease," Advances in Chronic Kidney Disease, vol. 17, no. 2, pp. 140-152, 2010.

[55] V. E. Torres, D. M. Wilson, R. R. Hattery, and J. W. Segura, "Renal stone disease in autosomal dominant polycystic kidney disease," American Journal of Kidney Diseases, vol. 22, no. 4, pp. 513-519, 1993.

[56] Y. Pirson, "Extrarenal manifestations of autosomal dominant polycystic kidney disease," Advances in Chronic Kidney Disease, vol. 17, no. 2, pp. 173-180, 2010.

[57] G. F. Gibbs, J. Huston, QI. Qian et al., "Follow-up of intracranial aneurysms in autosomal-dominant polycystic kidney disease," Kidney International, vol. 65, no. 5, pp. 16211627, 2004.

[58] K. Neldner and B. Struk, "Pseudoxanthoma elasticum," in Connective Tissue and Its Heritable Disorders, pp. 561-583, Wiley-Liss, New York, NY, USA, 2002.

[59] O. M. Vanakker, B. P. Leroy, P. Coucke et al., "Novel clinicomolecular insights in pseudoxanthoma elasticum provide an efficient molecular screening method and a comprehensive diagnostic flowchart," Human mutation, vol. 29, no. 1, p. 205, 2008.

[60] O. Le Saux, Z. Urban, C. Tschuch et al., "Mutations in a gene encoding an $\mathrm{ABC}$ transporter cause pseudoxanthoma elasticum," Nature Genetics, vol. 25, no. 2, pp. 223-227, 2000.

[61] O. M. Vanakker, L. Martin, L. J. Schurgers et al., "Low serum vitamin $\mathrm{K}$ in PXE results in defective carboxylation of mineralization inhibitors similar to the GGCX mutations in the PXE-like syndrome," Laboratory Investigation, vol. 90, no. 6, pp. 895-905, 2010.

[62] A. Bock and G. Schwegler, "Intracerebral haemorrhage as first manifestation of Pseudoxanthoma elasticum," Clinical
Neurology and Neurosurgery, vol. 110, no. 3, pp. 262-264, 2008.

[63] S. Van Soest, J. Swart, N. Tijmes, L. A. Sandkuijl, J. Rommers, and A. A. B. Bergen, "A locus for autosomal recessive pseudoxanthoma elasticum, with penetrance of vascular symptoms in carriers, maps to chromosome 16p13.1," Genome Research, vol. 7, no. 8, pp. 830-834, 1997.

[64] J. J. Wegman, X. Hu, H. Tan et al., "Patients with premature coronary artery disease who carry the ABCC6 R1141X mutation have no Pseudoxanthoma Elasticum phenotype," International Journal of Cardiology, vol. 100, no. 3, pp. 389393, 2005.

[65] G. Köblös, H. Andrikovics, Z. Prohászka, A. Tordai, A. Váradi, and T. Arányi, "The R1141X loss-of-function mutation of the ABCC6 gene is a strong genetic risk factor for coronary artery disease," Genetic Testing and Molecular Biomarkers, vol. 14, no. 1, pp. 75-78, 2010.

[66] O. M. Vanakker, L. Martin, D. Gheduzzi et al., "Pseudoxanthoma elasticum-like phenotype with cutis laxa and multiple coagulation factor deficiency represents a separate genetic entity," Journal of Investigative Dermatology, vol. 127, no. 3, pp. 581-587, 2007.

[67] P. Bhatnagar, K. B. Freund, R. F. Spaide et al., "Intravitreal bevacizumab for the management of choroidal neovascularization in pseudoxanthoma elasticum," Retina, vol. 27, no. 7, pp. 897-902, 2007.

[68] V. Cãadas, I. Vilacosta, I. Bruna, and V. Fuster, "Marfan syndrome. Part 1: pathophysiology and diagnosis," Nature Reviews Cardiology, vol. 7, no. 5, pp. 256-265, 2010.

[69] P. N. Robinson, E. Arteaga-Solis, C. Baldock et al., "The molecular genetics of Marfan syndrome and related disorders," Journal of Medical Genetics, vol. 43, no. 10, pp. 769787, 2006.

[70] P. C. Spittell, J. A. Spittell, J. W. Joyce et al., "Clinical features and differential diagnosis of aortic dissection: experience with 236 cases (1980 through 1990)," Mayo Clinic Proceedings, vol. 68, no. 7, pp. 642-651, 1993.

[71] M. G. Austin and R. F. Schaeffer, "Marfan's syndrome with unusual blood vessel manifestations," American Medical Association, vol. 64, pp. 205-209, 1957.

[72] R. J. Wityk, C. Zanferrari, and S. Oppenheimer, "Neurovascular complications of Marfan syndrome: a retrospective, hospital-based study," Stroke, vol. 33, no. 3, pp. 680-684, 2002.

[73] J. E. Conway, G. M. Hutchins, and R. J. Tamargo, "Marfan syndrome is not associated with intracranial aneurysms," Stroke, vol. 30, no. 8, pp. 1632-1636, 1999.

[74] W. I. Schievink, R. J. Tamargo, J. E. Conway, and G. M. Hutchins, "Marfan syndrome and intracranial aneurysms," Stroke, vol. 30, no. 12, pp. 2767-2768, 1999.

[75] B. L. Loeys, H. C. Dietz, A. C. Braverman et al., "The revised Ghent nosology for the Marfan syndrome," Journal of Medical Genetics, vol. 47, no. 7, pp. 476-485, 2010.

[76] J. C. S. Dean, "Marfan syndrome: clinical diagnosis and management," European Journal of Human Genetics, vol. 15, no. 7, pp. 724-733, 2007.

[77] P. Matt, J. Habashi, T. Carrel, D. E. Cameron, J. E. Van Eyk, and H. C. Dietz, "Recent advances in understanding Marfan syndrome: should we now treat surgical patients with losartan?" Journal of Thoracic and Cardiovascular Surgery, vol. 135, no. 2, pp. 389-394, 2008.

[78] B. L. Loeys, J. Chen, E. R. Neptune et al., "A syndrome of altered cardiovascular, craniofacial, neurocognitive and 
skeletal development caused by mutations in TGFBR1 or TGFBR2," Nature Genetics, vol. 37, no. 3, pp. 275-281, 2005.

[79] B. L. Loeys, U. Schwarze, T. Holm et al., "Aneurysm syndromes caused by mutations in the TGF- $\beta$ receptor," New England Journal of Medicine, vol. 355, no. 8, pp. 788-798, 2006.

[80] M. D. Everitt, N. Pinto, J. A. Hawkins, M. B. Mitchell, P. C. Kouretas, and A. T. Yetman, "Cardiovascular surgery in children with Marfan syndrome or Loeys-Dietz syndrome," Journal of Thoracic and Cardiovascular Surgery, vol. 137, no. 6, pp. 1327-1333, 2009.

[81] S. A. LeMaire, H. Pannu, V. Tran-Fadulu, S. A. Carter, J. S. Coselli, and D. M. Milewicz, "Severe aortic and arterial aneurysms associated with a TGFBR2 mutation," Nature Clinical Practice Cardiovascular Medicine, vol. 4, no. 3, pp. 167-171, 2007.

[82] M. L. Williams, S. B. Wechsler, and G. C. Hughes, "Two-stage total aortic replacement for Loeys-dietz syndrome," Journal of Cardiac Surgery, vol. 25, no. 2, pp. 223-224, 2010.

[83] C. Ward, "Clinical significance of the bicuspid aortic valve," Heart, vol. 83, no. 1, pp. 81-85, 2000.

[84] P. W. M. Fedak, S. Verma, T. E. David, R. L. Leask, R. D. Weisel, and J. Butany, "Clinical and pathophysiological implications of a bicuspid aortic valve," Circulation, vol. 106, no. 8, pp. 900-904, 2002.

[85] L. Cripe, G. Andelfinger, L. J. Martin, K. Shooner, and D. W. Benson, "Bicuspid aortic valve is heritable," Journal of the American College of Cardiology, vol. 44, no. 1, pp. 138-143, 2004.

[86] V. Garg, A. N. Muth, J. F. Ransom et al., "Mutations in NOTCH1 cause aortic valve disease," Nature, vol. 437, no. 7056, pp. 270-274, 2005.

[87] M. Wolf and C. T. Basson, "The molecular genetics of congenital heart disease: a review of recent developments," Current Opinion in Cardiology, vol. 25, no. 3, pp. 192-197, 2010.

[88] W. I. Schievink and B. Mokri, "Familial aortocervicocephalic arterial dissections and congenitally bicuspid aortic valve," Stroke, vol. 26, no. 10, pp. 1935-1940, 1995.

[89] W. I. Schievink, B. Mokri, D. G. Piepgras, and A. C. Gittenberger-de Groot, "Intracranial aneurysms and cervicocephalic arterial dissections associated with congenital heart disease," Neurosurgery, vol. 39, no. 4, pp. 685-689, 1996.

[90] W. I. Schievink, "Intracranial aneurysms," The New England Journal of Medicine, vol. 336, pp. 28-40, 1997.

[91] W. I. Schievink, S. S. Raissi, M. M. Maya, and A. Velebir, "Screening for intracranial aneurysms in patients with bicuspid aortic valve," Neurology, vol. 74, no. 18, pp. 1430$1433,2010$.

[92] S. C. Siu and C. K. Silversides, "Bicuspid aortic valve disease," Journal of the American College of Cardiology, vol. 55, no. 25, pp. 2789-2800, 2010.

[93] P. Franceschini, A. Guala, D. Licata, G. Di Cara, and D. Franceschini, "Arterial tortuosity syndrome," American Journal of Medical Genetics, vol. 91, no. 2, pp. 141-143, 2000.

[94] B. L. Callewaert, A. Willaert, W. S. Kerstjens-Frederikse et al., "Arterial tortuosity syndrome: clinical and molecular findings in 12 newly identified families," Human Mutation, vol. 29 , no. 1, pp. 150-158, 2008.

[95] P. J. Coucke, A. Willaert, M. W. Wessels et al., "Mutations in the facilitative glucose transporter GLUT10 alter angiogenesis and cause arterial tortuosity syndrome," Nature Genetics, vol. 38, no. 4, pp. 452-457, 2006.
[96] B. A. Pletcher, J. E. Fox, R. A. Boxer et al., "Four sibs with arterial tortuosity: description and review of the literature," American Journal of Medical Genetics, vol. 66, no. 2, pp. 121128, 1996.

[97] M. S. Cartwright, W. H. Hickling, and E. S. Roach, "Ischemic stroke in an adolescent with arterial tortuosity syndrome," Neurology, vol. 67, no. 2, pp. 360-361, 2006.

[98] C. Stamm, I. Friehs, S. Y. Ho, A. M. Moran, R. A. Jonas, and P. J. Del Nido, "Congenital supravalvar aortic stenosis: a simple lesion?" European Journal of Cardio-thoracic Surgery, vol. 19, no. 2, pp. 195-202, 2001.

[99] B. R. Pober, "Williams-Beuren syndrome," New England Journal of Medicine, vol. 362, no. 3, pp. 239-252, 2010.

[100] C. A. Morris, "Genetic aspects of supravalvular aortic stenosis," Current Opinion in Cardiology, vol. 13, no. 3, pp. 214-219, 1998.

[101] D. Kitchiner, M. Jackson, K. Walsh, I. Peart, and R. Arnold, "Prognosis of supravalve aortic stenosis in 81 patients in Liverpool (1960-1993)," Heart, vol. 75, no. 4, pp. 396-402, 1996.

[102] J. B. Wollack, M. Kaifer, M. P. Lamonte, and M. Rothman, "Stroke in Williams syndrome," Stroke, vol. 27, no. 1, pp. 143146, 1996.

[103] T. Kalbhenn, L. M. Neumann, W. R. Lanksch, and H. Haberl, "Spontaneous intracerebral hemorrhage and multiple infarction in Williams-Beuren syndrome," Pediatric Neurosurgery, vol. 39, no. 6, pp. 335-338, 2003.

[104] W. I. Schievink, "Spontaneous dissection of the carotid and vertebral arteries," New England Journal of Medicine, vol. 344, no. 12, pp. 898-906, 2001.

[105] K. Mondon, B. De Toffol, G. Georgesco et al., "Dissections simultanées des deux artères carotides internes et des deux artères vertébrales révélatrices d'un Syndrome d'EhlersDanlos type IV," Revue Neurologique, vol. 160, pp. 478-482, 2004.

[106] S. Rouvière, R. Michelini, P. Sarda, and M. Pagès, "Spontaneous carotid artery dissection in two siblings with osteogenesis imperfecta," Cerebrovascular Diseases, vol. 17, no. 2-3, pp. 270-272, 2004.

[107] S. A. Mayer, B. S. Rubin, B. J. Starman, and P. H. Byers, "Spontaneous multivessel cervical artery dissection in a patient with a substitution of alanine for glycine (G13A) in the $\alpha 1$ (I) chain of type I collagen," Neurology, vol. 47, no. 2, pp. 552-556, 1996.

[108] I. Hausser, U. Müller, S. Engelter et al., "Different types of connective tissue alterations associated with cervical artery dissections," Acta Neuropathologica, vol. 107, no. 6, pp. 509514, 2004.

[109] F. Von Pein, M. Välkkilä, R. Schwarz et al., "Analysis of the COL3A1 gene in patients with spontaneous cervical artery dissections," Journal of Neurology, vol. 249, no. 7, pp. 862866, 2002.

[110] C. Grond-Ginsbach, R. Weber, J. Haas et al., "Mutations in the COL5A1 coding sequence are not common in patients with spontaneous cervical artery dissections," Stroke, vol. 30, no. 9, pp. 1887-1890, 1999.

[111] C. Grond-Ginsbach, F. Wigger, M. Morcher et al., "Sequence analysis of the COL5A2 gene in patients with spontaneous cervical artery dissections," Neurology, vol. 58, no. 7, pp. 1103-1105, 2002.

[112] M. Morcher, I. Hausser, T. Brandt, and C. Grond-Ginsbach, "Heterozygous carriers of Pseudoxanthoma elasticum were not found among patients with cervical artery dissections," Journal of Neurology, vol. 250, no. 8, pp. 983-986, 2003. 
[113] S. Debette, T. M. Metso, A. Pezzini et al., "CADISP-genetics: an International project searching for genetic risk factors of cervical artery dissections," International Journal of Stroke, vol. 4, no. 3, pp. 224-230, 2009.

[114] W. I. Schievink, B. Mokri, D. G. Piepgras, and J. D. Kuiper, "Recurrent spontaneous arterial dissections: risk in familial versus nonfamilial disease," Stroke, vol. 27, no. 4, pp. 622624, 1996.

[115] J. J. Martin, I. Hausser, P. Lyrer et al., "Familial cervical artery dissections: clinical, morphologic, and genetic studies," Stroke, vol. 37, no. 12, pp. 2924-2929, 2006.

[116] T. Brandt and C. Grond-Ginsbach, "Spontaneous cervical artery dissection: from risk factors toward pathogenesis," Stroke, vol. 33, no. 3, pp. 657-658, 2002.

[117] A. E. Guttmacher, D. A. Marchuk, and R. I. White Jr., "Hereditary hemorrhagic telangiectasia," New England Journal of Medicine, vol. 333, no. 14, pp. 918-924, 1995.

[118] K. A. McAllister, K. M. Grogg, D. W. Johnson et al., "Endoglin, a TGF- $\beta$ binding protein of endothelial cells, is the gene for hereditary haemorrhagic telangiectasia type 1," Nature Genetics, vol. 8, no. 4, pp. 345-351, 1994.

[119] G. Lesca, H. Plauchu, F. Coulet et al., "Molecular Screening of ALK1/ACVRL1 and ENG Genes in Hereditary Hemorrhagic Telangiectasia in France," Human Mutation, vol. 23, no. 4, pp. 289-299, 2004.

[120] M. E. M. Porteous, A. Curtis, O. Williams, D. Marchuk, S. S. Bhattacharya, and J. Burn, "Genetic heterogeneity in hereditary haemorrhagic telangiectasia," Journal of Medical Genetics, vol. 31, no. 12, pp. 925-926, 1994.

[121] T. G. W. Letteboer, J. J. Mager, R. J. Snijder et al., "Genotypephenotype relationship in hereditary haemorrhagic telangiectasia," Journal of Medical Genetics, vol. 43, no. 4, pp. 371377, 2006.

[122] M. J. McDonald, B. P. Brophy, and C. Kneebone, "RenduOsler-Weber syndrome: a current perspective on cerebral manifestations," Journal of Clinical Neuroscience, vol. 5, no. 3, pp. 345-350, 1998.

[123] N. K. Singh and R. Kolluri, "Paradoxical systemic embolization in hereditary hemorrhagic telangiectasia," Circulation. Cardiovascular imaging, vol. 1, no. 2, pp. e11-e12, 2008.

[124] P. Bose, J. L. Holter, and G. B. Selby, "Bevacizumab in hereditary hemorrhagic telangiectasia," New England Journal of Medicine, vol. 360, no. 20, pp. 2143-2144, 2009.

[125] F. S. Govani and C. L. Shovlin, "Hereditary haemorrhagic telangiectasia: a clinical and scientific review," European Journal of Human Genetics, vol. 17, no. 7, pp. 860-871, 2009.

[126] R. Zarrabeitia, V. Albiñana, M. Salcedo, B. Señaris-Gonzalez, J.-L. Fernandez-Forcelledo, and L.-M. Botella, "A review on clinical management and pharmacological therapy on hereditary haemorrhagic telangiectasia (HHT)," Current Vascular Pharmacology, vol. 8, no. 4, pp. 473-481, 2010.

[127] P. F. Plouin, J. Perdu, A. La Batide-Alanore, P. Boutouyrie, A. P. Gimenez-Roqueplo, and X. Jeunemaitre, "Fibromuscular dysplasia," Orphanet Journal of Rare Diseases, vol. 2, no. 1, article 28, 2007.

[128] J. C. Stanley, "Renal artery fibrodysplasia," in Renal Vascular Disease, A. C. Novick, J. Scable, and G. Hamilton, Eds., pp. 21-23, WB Saunders, London, UK, 1996.

[129] K. L. Mettinger, "Fibromuscular dysplasia and the brain. II. Current concept of the disease," Stroke, vol. 13, no. 1, pp. 53$58,1982$.

[130] H. J. Cloft, D. F. Kallmes, M. H. Kallmes, J. H. Goldstein, M. E. Jensen, and J. E. Dion, "Prevalence of cerebral aneurysms in patients with fibromuscular dysplasia: a reassessment," Journal of Neurosurgery, vol. 88, no. 3, pp. 436-440, 1998.

[131] K. R. Stahlfeld, J. R. Means, and P. Didomenico, "Carotid artery fibromuscular dysplasia," American Journal of Surgery, vol. 193, no. 1, pp. 71-72, 2007.

[132] M. C. CONNETT and J. M. LANSCHE, "Fibromuscular hyperplasia of the internal carotid artery: report of a case," Annals of surgery, vol. 162, pp. 59-62, 1965.

[133] H. Van Damme, N. Sakalihasan, and R. Limet, "Fibromuscular dysplasia of the internal carotid artery. Personal experience with 13 cases and literature review," Acta Chirurgica Belgica, no. 4, pp. 163-168, 1999.

[134] L. Chiche, A. Bahnini, F. Koskas, and E. Kieffer, "Occlusive fibromuscular disease of arteries supplying the brain: results of surgical treatment," Annals of Vascular Surgery, vol. 11, no. 5, pp. 496-504, 1997.

[135] L. A. Dayes and N. Gardiner, "The neurological implications of fibromuscular dysplasia," Mount Sinai Journal of Medicine, vol. 72, no. 6, pp. 418-420, 2005.

[136] E. Touzé, C. Oppenheim, D. Trystram et al., "Fibromuscular dysplasia of cervical and intracranial arteries," International Journal of Stroke, vol. 5, no. 4, pp. 296-305, 2010.

[137] A. Flex, E. Gaetani, P. Papaleo et al., "Proinflammatory genetic profiles in subjects with history of ischemic stroke," Stroke, vol. 35, no. 10, pp. 2270-2275, 2004.

[138] S. Ye, P. Eriksson, A. Hamsten, M. Kurkinen, S. E. Humphries, and A. M. Henney, "Progression of coronary atherosclerosis is associated with a common genetic variant of the human stromelysin-1 promoter which results in reduced gene expression," Journal of Biological Chemistry, vol. 271, no. 22, pp. 13055-13060, 1996.

[139] Y. M. Ruigrok, G. J. E. Rinkel, and C. Wijmenga, "The versican gene and the risk of intracranial aneurysms," Stroke, vol. 37, no. 9, pp. 2372-2374, 2006.

[140] Y. M. Ruigrok, G. J. E. Rinkel, C. Wijmenga et al., "Association analysis of genes involved in the maintenance of the integrity of the extracellular matrix with intracranial aneurysms in a Japanese cohort," Cerebrovascular Diseases, vol. 28, no. 2, pp. 131-134, 2009.

[141] J. T. Powell, "Abdominal aortic aneurysm," in An Introduction to Vascular Biology, A. Halliday, B. J. Hunt, L. Poston, and M. Schachter, Eds., pp. 166-172, Cambridge University Press, Cambridge, UK, 1998.

[142] D. G. Peters, A. Kassam, P. L. ST. Jean, H. Yonas, and R. E. Ferrell, "Functional polymorphism in the matrix metalloproteinase-9 promoter as a potential risk factor for intracranial aneurysm," Stroke, vol. 30, no. 12, pp. 26122616, 1999.

[143] B. Zhang, S. Dhillon, I. Geary et al., "Polymorphisms in matrix metalloproteinase-1, $-3,-9$, and -12 genes in relation to subarachnoid hemorrhage," Stroke, vol. 32, no. 9, pp. 2198-2202, 2001.

[144] G. J. del Zoppo, "The neurovascular unit, matrix proteases, and innate inflammation," Annals of the New York Academy of Sciences, vol. 1207, pp. 46-49, 2010. 


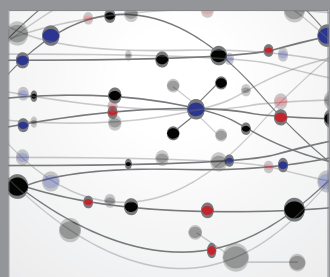

The Scientific World Journal
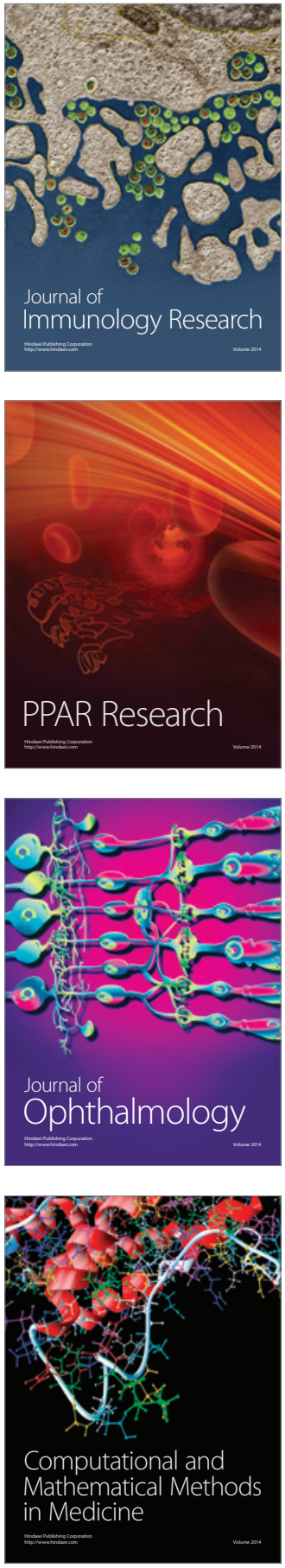

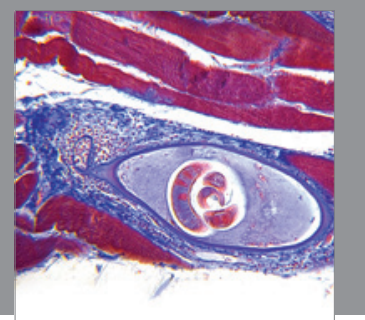

Gastroenterology

Research and Practice
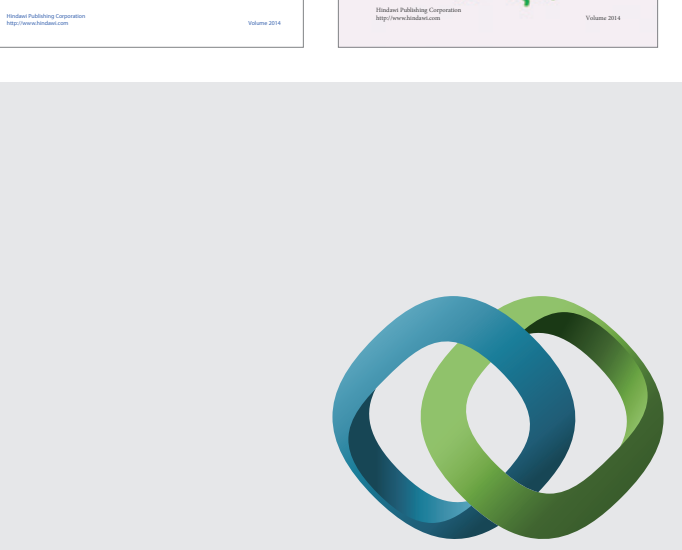

\section{Hindawi}

Submit your manuscripts at

http://www.hindawi.com
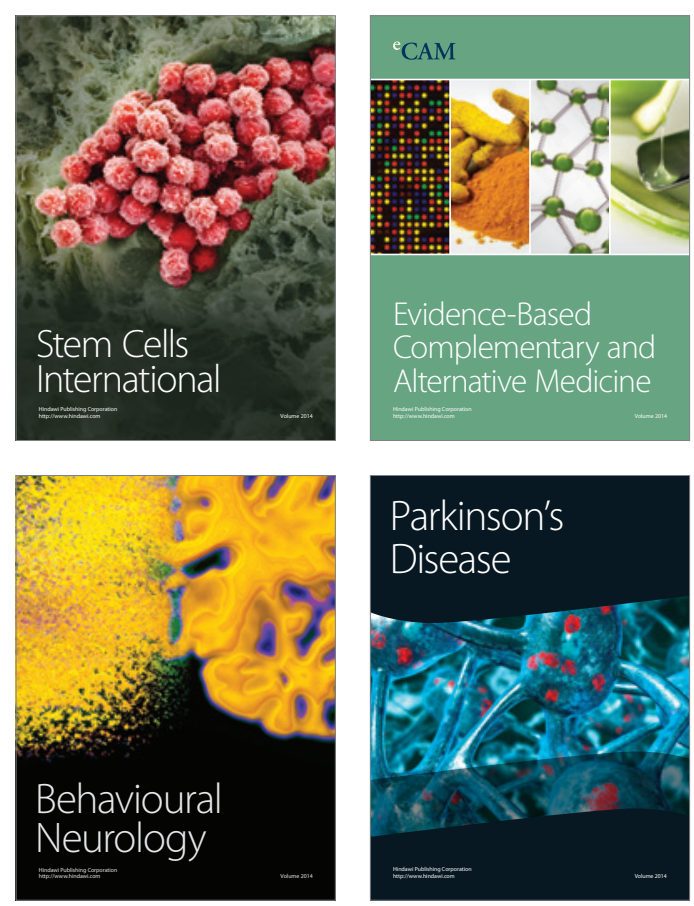

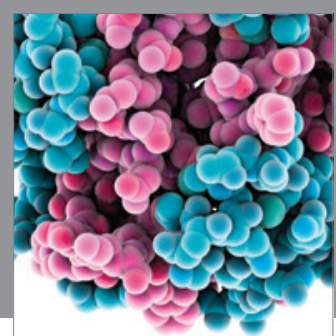

Journal of
Diabetes Research

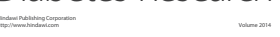

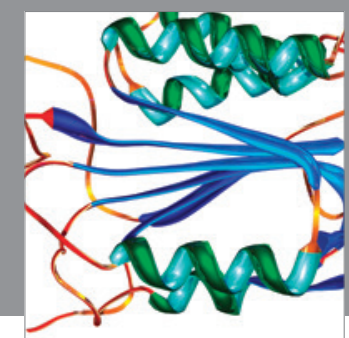

Disease Markers
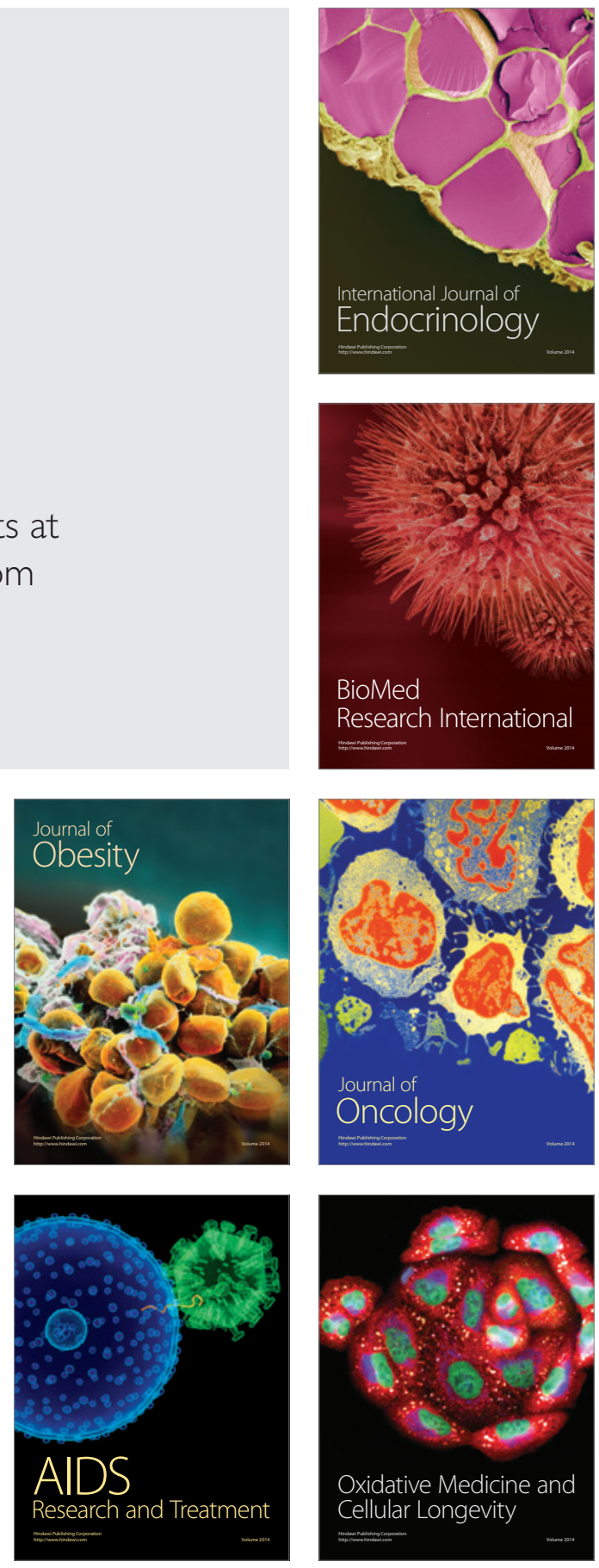